Accepted refereed manuscript of:

Mcmillan DG (2019) Cross-Asset Relations, Correlations and Economic Implications. Global Finance Journal, 41, pp. 60-78. DOI: https://doi.org/10.1016/j.gfj.2019.02.003

(C) 2019, Elsevier. Licensed under the Creative Commons Attribution-NonCommercial-NoDerivatives 4.0 International http://creativecommons.org/licenses/by-nc-nd/4.0/

\title{
Cross-Asset Relations, Correlations and Economic Implications
}

\author{
David G McMillan \\ Division of Accounting and Finance \\ University of Stirling
}

August 2018

Revised December 2018

This Version February 2019

\begin{abstract}
This paper examines the interrelations and time-varying correlations for eight assets. Oneyear rolling correlations reveal that each of the 28 correlations exhibit both positive and negative values. Linear regressions reveal that given macroeconomic and financial variables contain predictive power for different asset return correlations. The term structure of interest rates and consumer sentiment feature as prominent predictor variables. Structural break tests and non-linear regressions indicate a cycling of correlations between high and low risk periods. In seeking to consider the economic content of the interrelations, we construct a safe and risky portfolio and show that the correlation between these portfolios can allow for improved market timing. Further, the safe and risky portfolio returns and correlation exhibit predictive power for macroeconomic conditions and may be used in a leading indicator role. The results presented here should be of interest to investors and policy-makers as well as academics wishing to examine the relations between both asset returns and financial and real markets.
\end{abstract}

Keywords: Time-Varying Correlations, Cross-Asset, Rolling Windows, Markov Switching, Macroeconomic, Prediction

JEL Codes: C22, G12

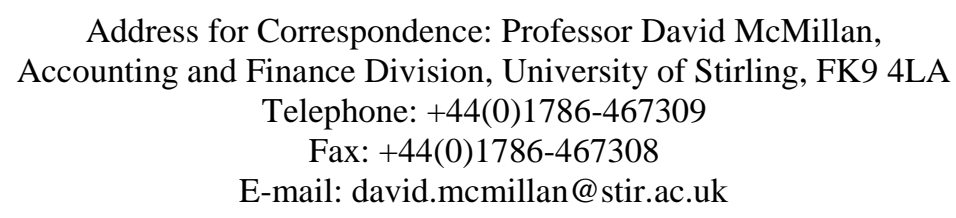

Acknowledgements: the author gratefully acknowledges the helpful comments from the editor and an anonymous referee that have allowed me to revise and improve the paper.

Funding: This research did not receive any specific grant from funding agencies in the public, commercial, or not-for-profit sectors. 


\section{Introduction.}

Understanding the interrelations between assets, including the nature of cross-asset correlation, is important for both investors and economic policy-makers given their potential implications for portfolio management and expected economic conditions. For example, the interrelation between the returns of stocks, bonds and gold contains information with regard to investor expectations of the future outlook for the economy. Under normal economic conditions when investors are optimistic about the future course of the economy, they are likely to enhance their holdings of stocks and bonds within a diversified portfolio. This will lead to a positive correlation between these two assets. During such periods, these assets are also likely to exhibit a negative correlation with gold returns. As the latter bears no income, it is likely to be shunned when investors are optimistic. In contrast, during periods when investors become pessimistic with regard to future economic conditions, the nature and sign of the correlations will change. As expected economic performance declines investors may adopt a flight-to-safety position, selling stocks in favour of bonds. This results in a declining positive and subsequently negative correlation between stocks and bonds. Equally, investors may seek out gold as a safe haven asset, and while this still implies a negative correlation between stocks and gold, it may lead to a positive correlation between bonds and gold. Hence, the correlation between asset classes can be informative in regard of investor expectations and may contain leading indicator information for the wider economy. Thus, understanding the drivers of such correlations is important as this imparts information not only about asset price movement but also about future economic prospects.

A relatively large body of work examines the nature of the stock and bond correlation from a variety of perspectives. Indeed, as the largest two asset classes, they dominate academic research on cross-asset behaviour. Barksy (1989), Shiller and Beltratti (1992) and Campbell and Ammer (1993) all highlight a positive correlation between stocks and bonds, 
while a negative correlation linked to flight-to-safety is noted by, for example, Gulko (2002), Connolly et al $(2005,2007)$ and Andersson et al (2008). In seeking to understand the dynamics of this relation, a series of papers (e.g., Baele et al, 2010; Aslanidis and Christiansen, 2012, 2014) consider a range of macroeconomic and financial explanatory variables. Related work that defines the relation between stocks and bonds in a different manner equally highlights the role of established macroeconomic and financial variables in explaining their dynamic behaviour. For example, Viceira (2012) and Campbell et al (2017) define the relation in terms of the bond beta (the covariance between stock and bond returns standardised by the variance of the stock return) and examine the determinants of this variable.

Away from the stock and bond correlation, there is relatively less work examining the drivers of cross-asset correlations. Baur and Lucey (2010) examine the relation between stocks, bonds and gold, notably, considering the hedging or diversification properties of gold. Discussion with regard to the relation between stocks and commodities tends to focus on the, so-called, financialisation of commodities, where the relation with stocks has strengthened over time (see, for example, Falkowski, 2011; Tang and Xiong, 2012; Basek and Pavlova, 2016). Other authors have sought to consider whether commodities provide any predictive power for stocks, volatility and economic activity (see, for example, Bakshi et al, 2011; Vivian and Wohar, 2012; Creti et al, 2013; Jacobsen et al, 2013; Black et al, 2014; Olson et al, 2014).

This, therefore, leaves a gap in our understanding of how the interactions and correlations across a range of assets move. This is particularly pertinent given the dramatic changes in asset price behaviour over the last twenty years or so. For example, we have seen the dramatic fall in stock prices following the burst of the dotcom bubble, with an accompanying fall in interest rates designed to cushion the blow for investors. The increase 
of commodities in portfolio holdings as investors sought higher yields. The subsequent recovery of stocks before the crash and recovery from the financial crisis period, while interest rates fell even lower. This has led researchers to argue that the nature of cross-asset correlations has changed. For example, Baele et al (2010) and Viceira (2012), among others, note that the stock and bond return correlation has moved from positive to negative since 2000. Further, the nature of correlations with commodities has strengthened with the financialisation of commodities as stock and bond yields were low (e.g., Cheng and Xiong, 2013; Basak and Pavlova, 2016).

Thus, our interest lies in both seeking to understand how the correlations between assets change over time and whether there is a set of conditioning variables that can explain the movement in correlations. Further, we are equally interested in whether this information has predictive power for subsequent movements in portfolio returns and economic activity. A long-standing line of research seeks to examine whether financial variables, typically stock and bond returns, exhibit predictive power for different measures of output (see, for example, Schwert, 1990; Stock and Watson, 1990; Estrella and Hardouvelis, 1991; Hardouvelis, 1994; Venetis et al, 2003; Henry et al, 2004; Lange, 2018). Given the above discussion it is pertinent to ask whether the joint movements of assets through their correlation also has such predictive power.

This paper, therefore, considers two related issues. First, we seek to examine the nature of the correlations across a range of assets and consider whether this movement is driven by a set of macroeconomic and financial variables. Taking the perspective of a US based investor, we consider the correlation behaviour across US and world stocks, government and corporate bonds, commodities, gold, real estate and the exchange rate. Using a common set of explanatory variables, we examine whether the correlations across these different assets are driven by the same common set of variables, or whether different subsets 
of variables impact different asset correlations. In considering this, we additionally allow for time-variation in the nature of the predictive relations. Second, the paper subsequently examines whether there is information contained in asset returns and the movement between assets that contains predictive power for portfolios and economic activity.

The key results arising from this analysis reveal a substantial amount of time-variation within each of the correlation series, with all exhibiting positive and negative values. In understanding these movements, the term structure of interest rates, the purchasing managers index and consumer sentiment are the most prominent explanatory variables. Moreover, breakpoint tests and a non-linear model reveal differing dynamics between positive and negative correlation values. To examine the economic implications, we construct a risky and safe portfolio from our eight assets and demonstrate that the correlation between these portfolios can help in market timing decisions. Further, the portfolio returns and correlation have predictive power for subsequent economic performance. We believe that the results within this paper are of relevance to both academics and investors interested in understanding the movement of different assets as well as policy-makers interested in the leading indicator potential of financial markets.

\section{Data and Correlations.}

We examine the correlation dynamics for a set of eight financial return series, sampled at the monthly frequency over the period 1975:1 to 2017:6. The asset return data is for US stocks, world stocks (excluding the US), US 10-year Treasury bonds, US BAA rated corporate bonds, a general commodity index (the S\&P GSCI), gold, a US REIT (real estate investment trust) index and a dollar exchange rate index. ${ }^{1,2}$ All the data is obtained from DataStream. Table 1 presents summary statistics for these asset return series. The characteristics of

\footnotetext{
${ }^{1}$ For each series, we obtain the index level and generate returns using the first-difference of the log series.

${ }^{2}$ The GSCI is dominated by the energy sector, which has a weighting of approximately $80 \%$ in the index. Gold accounts for less than $2 \%$, so there is unlikely to be an collinearity between these series.
} 
financial data are well-known and repeated here, we observe that each series has a higher standard deviation than return and exhibits non-normality. We do not provide plots of the index data series (again as the movements in such assets are largely well-known, but they are available upon request). Nonetheless, in lieu of the plots, the pertinent points that affect the series include the rising stock market during the 1990s that culminates in the dotcom bubble. Accompanying this rise, is a flatlining or falling gold price. Throughout the sample, the bond index shows steady growth, while the corporate bond series exhibits a greater degree of volatility and a lower level of growth. With the bursting of the dotcom bubble and the financial crisis, the gold market responds positively to these stock market crises. A steepening of the commodity price trend occurs following the dotcom burst and up to the financial crisis. As stock markets recover from the financial crisis, a fall in both the gold and commodity prices occurs. The real estate index shows relatively stable growth throughout the sample period but with a noticeable rise in the early 2000s and fall during the financial crisis. The corporate bond series also reports a large drop at this latter point in time. The dollar periodically exhibited times of relative strength and weakness, being notably strong in the early 1980s, the early 2000s and the mid-2010s. Overall, even this casual description indicates that the nature of the interrelations between the series appears to vary over time, with periods of positive and negative association.

An obvious issue is how to generate the correlations between the different assets. This arises as the correlation itself is an unobserved variable and so different approaches have been suggested to proxy for it. A range of approaches are considered within the existing literature. A common method is to use some form of the GARCH modelling approach, which allows for the joint modelling of asset returns and their covariance. Examples of this include, Baur and Lucey (2010) who use a multivariate-GARCH model and Colacito et al (2011) who use an extension of the DCC model of Engle (2002). An alternative approach builds upon the 
realised volatility literature (see, McAleer and Medeiros, 2008, for a general review) and seeks to construct a realised correlation series. This includes the work of Aslanidis and Christiansen (2012) and the more recent work of Ohmi and Okimoto (2016). Notwithstanding these approaches, a relatively simple way to obtain the time-varying correlation is through a moving window. Fan and Mitchell (2017) use a 1-year and 5-year rolling window to illustrate the nature of time-variation, while Rankin and Shah Idil (2014) consider a variety of window lengths. Regardless of the approach taken, each of these methods appears to produce correlation series that closely reflects each other and only differs in the variability of the constructed correlation time series. As an example, Figure 1 of Baele et al (2010, p2376) highlights the greater variability in realised correlation approach compared to the DCC based approach of Colacito et al (2011).

We construct 1-year rolling correlations, which form the main basis of our analysis, but recognising that there is no single accepted approach, we also consider alternative measures. ${ }^{3}$ Figure 1 presents the time-series plots of the 28 -correlation series arising from the eight financial asset returns. Within these graphs we can observe a significant amount of time variation with each series exhibiting both positive and negative values. Of note, we can see that the correlation between the stock and bond returns exhibits a notable decline in the latter part of the sample period. A similar decline can be seen in the correlation between bond and commodity returns. This occurs at the same time the correlation between US and world stock returns rises, with a similar but less persistent rise in the stock and commodity return correlation. The bond and gold return and bond and dollar return correlations also appear to rise towards the end of the sample period. For the remaining correlations, they typically exhibit a high degree of cyclicality, with a possible downward trend for the corporate bond return and real estate index return correlation.

\footnotetext{
${ }^{3}$ We begin the analysis from the start of 1980 in order to provide comparability with the 5-year rolling window values.
} 
While it is difficult to explain the movement across the full range of correlation series, there is some potentially interlinked behaviour across the different assets. In the second half of the sample period, we can see a rise in the correlations between stock and commodity returns, US and world stock returns and bond and gold returns at the same time as the correlations between stock (notably US but also world) and bond returns and bond and commodity returns decline. Thus, we see the correlation between pairs of risky assets and pairs of safe assets rise at the same time as the correlation between a risky and safe asset falls. Without over-stressing this point, it does support the argument made by Baur (2010) who notes that stock return correlations across different markets increase when within country stock and bond correlations decline. The rationale for this behaviour is that assets of similar riskiness move together (contagion) when assets of differing risk move apart (flight-tosafety). While, Baur looks at stocks and bonds only, the results here suggest this may generalise across a wider range of asset classes.

As noted, there is no single method in which to obtain the correlation series. Therefore, to illustrate the nature of the correlations and differences (and similarities) that may occur with different approaches, Figure 2 plots the correlations achieved by the one-year rolling window used here together with a five-year rolling window and a symmetric DCCGARCH model for the stock and bonds return correlation and the REIT and dollar return correlation. As we can see, the different correlation series closely follow each other over much of the sample period. For the stock and bond returns correlation, the three series have a correlation between them of above 0.70 , while the correlation between the series obtained from the one-year rolling and DCC model approaches 0.90. For the three REIT and dollar return correlation series, the correlation between the two rolling window methods is above 0.5 and above 0.7 between the rolling and DCC series. Inevitably, the one-year rolling window correlation series exhibits the most variability, while the five-year rolling correlation 
produces the smoothest series. Also evident for both pairs of series, especially in the five-year correlation, is a step change in the nature of the correlations, being higher in the first half of the sample and lower in the second half. This also raises a key issue for the empirical analysis undertaken below. Across all the correlation series, and illustrated in Figure 2, is that the fiveyear rolling correlation, on the basis of a unit root test, exhibits non-stationarity, whereas the one-year correlation exhibits stationarity. Therefore, to ensure robustness of our empirical results, we focus on the one-year rolling window correlations. ${ }^{4}$

Using the one-year rolling correlations, Table 2 presents a set of summary statistics. From these statistics, it is of interest to examine the nature of the correlation between the eight different assets. Domestic US stock returns, on average, have a positive correlation with US government and corporate bond returns, world stock returns, REIT returns and commodity returns, with the magnitude on world stocks noticeably large, while the correlation with gold returns is negative. Domestic US bonds have, on average, a positive correlation with gold and REIT returns and negative correlation with commodity returns, while the correlation with corporate and world stock returns are essentially zero. Corporate bond returns have a positive correlation with world stock and REIT returns and essentially zero with commodity and gold returns. World stock returns have a positive correlation with commodity, gold and REIT returns, while REIT and gold returns are near zero. Dollar returns have a negative correlation with all other asset returns, thus a strengthening Dollar is associated with falling returns for all other assets.

The positive correlation, on average, between stocks, bonds and commodities can be seen as part of a portfolio diversification approach where investors spread their investments over several asset classes. The negative average correlation between stocks and gold can be seen to support the view of gold as a safe haven asset. The negative dollar correlation

\footnotetext{
${ }^{4}$ Similar graphs are available upon request. The pattern revealed on Figure 2 holds for the remaining correlation series, with the 5-year rolling and DCC approaches exhibiting a high correlation with the one-year rolling correlation used in the analysis.
} 
indicates that a rise in the value of the dollar is associated with a fall in the demand for assets that are denominated in dollars. Notwithstanding these general observations, Table 2 does illustrate, through the minimum and maximum values that all correlations cycle through both positive and negative values. ${ }^{5}$

\section{Explaining Correlations.}

Having obtained the correlations above, we use a common set of explanatory variables in a predictive regression model. This includes a range of both macroeconomic and financial variables that are considered in previous work. We include the change in the yield on the 3month Treasury bill, the difference between the yield on the 10-year Treasury bond and 3month Treasury bill, the difference in the log of the S\&P00 dividend-price ratio, the monthly change (difference log) in the consumer price index and industrial production, the purchasing managers index (PMI), a consumer sentiment index and the return on each asset. ${ }^{6}$ The use of a common set of predictor variables allows us to compare the explanatory factors across the range of assets, while we nonetheless acknowledge that there may be asset specific variables, we leave that examination for future research.

The above set of variables is consistent with that considered in previous work. For example, $\mathrm{Li}$ (2002) considers inflation and interest rates in examining the behaviour of the stock and bond return correlation. Baele et al (2010) likewise consider inflation and interest rates for the stock and bond correlation and additionally include a measure of output. Again, for the stock and bond correlation, Aslanidis and Christiansen $(2012,2014)$ use interest rates and inflation, while they also include the dividend-price ratio (as well as other valuation related variables). Viceira (2012) also considers interest rate and inflation variables together

\footnotetext{
${ }^{5}$ The rolling five-year correlations (not tabulated but available upon request) produce a similar set of summary statistics, although they suggest the gold-dollar and world stock-dollar return correlations are exclusively negative, while the US-world stock return correlation is exclusively positive.

${ }^{6}$ Again, we wish to ensure stationarity of the variables, which results in using the first difference of the 3-month Treasury bill and the log dividend-price ratio as they are non-stationary in levels.
} 
with the asset returns and macroeconomic variables (they include consumption growth whereas we use output growth). ${ }^{7}$ Aslanidis et al (2019) also include interest rates and a measure of output growth to explain movements in the stock and bond relation.

Overall, the choice of variables is motivated by using a set that is consistent with the previous research outlined above. While no single theoretical model links all the assets under examination here, we can broadly argue that these series are exposed to a common set of macroeconomic factors that will drive their movement and thus influence correlations. For example, a rise in interest rates is likely to see a fall in stock, bond and commodity prices. For the former two variables this occurs as the rise in interest rates will lead to an increase in the discount rate attached to future dividend and coupon payments respectively. For commodity prices, higher interest rates will signal lower future consumer demand and thus commodity demand for production. Additionally, as commodities do not attract any income stream, a higher interest rate will see investors moving out of commodities towards yield-producing assets. Gold, likewise, does not produce a yield and so higher interest rates will lead to a fall in the price of gold, although where this is linked to future economic risk then gold may act as a safe haven. In contrast, a higher interest rate will result in a strengthening of the US Dollar, as investors buy dollars to investors in dollar-denominated yielding assets. However, the nature of these relations is not monotonic, and several studies report that the correlation between stock and bond returns switches between positive (as suggested above) and negative values. For example, when interest rates fall, according to the above discussion we would expect stock and bond prices to rise as the discount rate falls. However, during an economic downturn, the lower interest rate may signal worsening economic conditions and thus a further fall in stock prices, while bond prices still rise. Such as effect has been highlighted by Humpe and McMillan (2016). Several researchers, notably Mamaysky (2002) and Li (2002),

\footnotetext{
${ }^{7}$ Some work includes the S\&P500 VIX implied volatility index, however, this is only available from 1990 onwards and thus does not cover the full sample used here.
} 
attempt to develop a unified stock and bond asset pricing model. Li (2002) notes that while interest rate shocks will lead to a positive relation, dividend or inflation shocks may reduce the correlation. While this research seeks to link stocks and bonds, no overarching model exists across the full range of assets.

Given the above, we include variables that indicate whether current economic performance is strong, for example, in terms of rising output, inflation and interest rates. With respect to financial market strength, the dividend-price ratio and the individual market asset returns provide such an indication. We also include the PMI and consumer sentiment index measures as indicators of firm and household expectations of future economic conditions. In order to provide comparability across our results, we use the same explanatory variables for all correlation pairs. Moreover, as discussed above, there is, a priori, reason to believe that the correlations will respond to movements in the same sets of variables.

We use this set of explanatory variables in the following regression for the cross-asset correlations:

$$
\rho_{i j, t}=\alpha_{0}+\Sigma_{i} \beta_{i} x_{i, t-1}+\varepsilon_{t}
$$

Where $\rho_{i j, t}$ refers to the correlation between assets $i$ and $j$ at time period $t, x_{i, t-1}$ are the explanatory variables noted above, lagged one period and $\varepsilon_{t}$ is the random error term. Prior to estimating the model, we take the Fisher transformation of the correlation series. A correlation is a bound variable, between -1 and 1 , so taking this transformation allows the series to be modelled as a continuous variable, which matches with the explanatory variables and the assumptions of the OLS regression model. The transformation is given by:

$$
z=0.5 \log (1+\rho) /(1-\rho)
$$

This $z$ variable is then used as the dependent variable in equation (1).

The results of estimating the model in equation (1) with the Fisher transform are presented in Table 3. In examining these results, we can observe whether a given explanatory 
variable exhibits a statistically significant (including up to the $10 \%$ level) relation across the correlations of given asset return series. Taking the key economic variables, we can see that the change in the short rate only has a very limited effect of the correlation series, with a 5\% significant relation for the corporate bond-REIT return correlation and a $10 \%$ significant effect of the stock-REIT return correlation. In terms of an increasing significant relation across the correlation series, the change in industrial production affects five series, the correlation pairs between stock-bond returns, stock-world stock returns and corporate bonds with world stock, commodity and REIT returns. The change in the dividend-price series has a significant effect on six correlation pairs, namely the bond return correlations with both US and world stocks, commodity and dollar returns as well as the correlations between corporate bond and REIT returns and world stock and gold returns (albeit at the 10\% significance level for this latter pair). Thus, the change in the dividend-price ratio has a significant effect on four of the bond return correlations. The purchasing managers index (PMI) is significant in seven correlation pairs. This is for stock-bond and stock-commodity return (at the $10 \%$ level) correlations, the bond-commodity returns correlation, the corporate bond-commodity (10\% level) and corporate bond-REIT return correlations and the correlations between the world stock and both commodity and REIT returns. Thus, PMI has a significant relation with four of the commodity return correlation series.

The term structure of interest rates affects nine correlation series, namely, the correlations for the stock-corporate bond, stock-gold, stock-dollar (10\% significance level), corporate bond-world stock, corporate bond-gold (10\% significance level), world stock-gold, commodity-gold, commodity-dollar and gold-dollar pairings. Thus, the term structure affects five gold return series correlations. The change in the consumer price index is significant in the stock-bond, stock-world stock, stock-dollar (10\% significance level), bond-corporate bond, bond-world stock, bond-gold, bond-dollar, corporate bond-REIT (10\% significance 
level) and commodity-dollar pairings. Thus, inflation has predictive power for nine correlations series and, of note, five bond return correlations. The consumer sentiment measure is significant across seventeen pairings and thus exhibits the most significance across the different explanatory variables. Consumer sentiment is significant in the correlation regressions for seven commodity return correlations, five stock and REIT return correlations, and four each for world stock and dollar return correlations. Specifically, stockbond, stock-commodity, stock-gold, Stock-REIT, stock-dollar, bond-world stock (10\% significance level), bond-commodity, bond-REIT (10\% significance level), corporate bondcommodity (10\% significance level), corporate bond-gold (10\% significance level), world stock-commodity, world stock-REIT, world stock-dollar, commodity-gold, commodityREIT, commodity-dollar and REIT-dollar pairings.

In seeking to provide an overview of these results, we can note where the explanatory variable is significant in more than half of the correlations regressions for each asset return. ${ }^{8}$ Thus, we can say that the term structure of interest rates predicts the movement in gold return correlations, the change in the dividend-price ratio, inflation and consumer sentiment predict movements in bond return correlations. PMI and consumer sentiment predict movements in commodity return correlations, while consumer sentiment also further predicts the movements in both US and world stock returns as well as REIT and dollar returns. There is also weaker evidence (i.e., in three of the correlation regressions for a given asset return) for the term structure and inflation to predict stock and dollar returns. The term structure also predicts corporate bond returns, which are also predicted by the change in industrial production. Gold returns are also predicted by consumer sentiment in three regressions.

In providing an economic explanation, the term structure and inflation are predictors of future economic conditions, thus movements in these variables may lead investors to

\footnotetext{
${ }^{8}$ That is in four or more regressions for each asset return.
} 
change their holdings of stocks, bonds and gold. The dividend-price ratio acts as a measure of valuation for stocks and thus movements in this value may affect investors holdings of bonds as the main alternative investment class to stocks. The purchasing managers index and consumer sentiment both have predictive power for commodities. This is consistent with the notion that changes in firm and household expectations will impact investment and consumption behaviour, which, in turn, will impact the demand for goods and thus affects commodity prices. Moreover, consumer sentiment has wider predictive power across stock and bond relations as it is likely to provide an indicator of investor risk preferences.

\section{Breaks.}

The above results present the nature of the relations between the correlations and the explanatory variables over the full sample from 1980 to 2017 . This time frame has seen numerous periods of market stress, crises and changes in economic conditions. A brief set of examples would include the stock market crash of 1987, the dotcom bubble and crash of the late 1990s and early 2000s, the financial crisis and subsequent recession starting in 2007, the Asian crisis of 1997, the Gulf war of the early 1990s and the Iraq invasion of 2003. These are all events that may affect the nature of cross asset correlations. Indeed, the graphical evidence presented in Figure 2 suggests a potential change in the nature of the correlation between both stock and bond and REIT and dollar returns around the late 1990s / early 2000s period.

Given this, we consider the stability of the above regression results by conducting the Bai and Perron (BP, 1998, 2003a,b) test for multiple breaks in the parameter values. The BP test is well-known and so to briefly state, the test sequentially examines the parameter values for breaks, starting from the null hypothesis of no breaks versus a single break using a $F$-test approach. We allow for up to five breaks in each regression and use a trimming value of $15 \%$, this means that at least $15 \%$ of the observations must lie between each break. 
For ease of presentation, Table 4 presents the statistically significant break dates, while the full set of test results is available upon request. In considering this table, we can identify groupings of dates that appear common across the majority of the correlations. Notably, we observe a number of the regression models indicating a break in the mid/late 1980s and particularly between 1985-1988. There is also evidence of a break in the early 1990s, with results indicating break around 1990-1992. Evidence of a break later in the 1990s is also noted, especially around 1997-1998. During the 2000s, there is evidence of a break around 2004-2005, as well as the post financial crisis period, after 2007. A break is also noted around the 2010-2011 period. In identifying events that surround these dates, this includes, the stock market crash of 1987, the Gulf war of the early 1990s (also the war in former Yugoslavia), the Asian financial crisis of 1997, the dotcom bubble that began in the second half of the 1990s, with the crash in the early 2000, the financial crisis that begin in 2007 and the European sovereign debt and US debt ceiling crisis periods. Recessionary periods are also identified during this sample for the US (identified by the NBER) and globally (identified by the IMF) in the early 1980s, 1990s, 2000s and late 2000s. This indicates some correspondence between the breaks and economic recessions (especially the early 1990s and late 2000 s periods) but also that some breaks are more related to financial events (especially the late 1980 s, mid 2000s and early 2010s). ${ }^{9}$

To illustrate the nature of the changing correlations across the time period, Figure 3 presents plots designed to provide such an overview. The graphs present the average correlation across the 28 individual correlations for each time period and the difference between the highest and lowest correlation across the 28 series, again, for each time period. A general view is that higher correlations are a signal of higher economic risk, as assets tend to

\footnotetext{
${ }^{9}$ For the 5-year rolling windows, breaks in the correlation series are observed over the periods 1987-1988, 1992-1994, 2002-2004 and 2008-2009. There is also limited evidence of breaks in the late 1990s and early 2010s.
} 
move together when markets are under stress, i.e., the idea that market fall together. ${ }^{10}$ The average correlation thus represents the average picture across the eight assets. However, of course, as Table 2 reveals, both positive and negative correlations exist across the assets. Therefore, the difference between the maximum and minimum correlations will highlight periods when the correlations across our assets strengthen and so this distance will increase and indicate a period of potentially heightened risk. ${ }^{11}$

Evident from Figure 3 is that across the correlations, the average correlation is higher at the start of the sample period in the early 1980 s, over the period from the mid to late 1990 s and the mid to late 2000s and towards the end of the sample period. In terms of the maximum minus minimum correlations, we see this distance being greater at the start of the sample period, during the early 1980s as well as in the early 1990s, the early 2000 s and towards the end of the sample, particularly from 2008 onwards. Indeed, we can see from the early 2000s this distance becoming increasingly larger, with only a small dip around 2005. As noted above, the higher correlations and the greater distance between the maximum and minimum correlations might signal an increase in risk as asset movements become more closely linked. The early 1980s is a period marked by global recession following the second OPEC oil price rise as well as high interest rates and a period of fiscal contraction. Equally, the early 1990s is marked by a recessionary period caused in part by rising interest rates in the late 1980s and oil price rises from the Gulf war. The period at the turn of the century follows the dotcom crash, while the period after 2008 is marked by the financial crisis and subsequent effects (e.g., the European sovereign debt and US debt ceiling crises). The higher correlations in the second half of the 1990s, which also is evidence in the maximum minus minimum graph, is a period associated with the Asian financial crisis and the start of the dotcom bubble.

\footnotetext{
10 For example, Reuters use a cross-asset correlation measure to illustrate the degree of risk, see, https://uk.reuters.com/article/us-markets-assets-analysis/rising-cross-asset-correlation-shows-more-fuel-for-selloff-idUKKCN1GL1GX

${ }^{11}$ We also examined the average absolute correlation and the standard deviation of the correlations across the eight assets with the resulting graphs very similar to that of the maximum minus minimum correlation graph.
} 
Overall, the results of this section indicate that the nature of correlations change over time, with notable shifts, or regime changes, in the late 1980s, the mid 1990s, the late 1990s/early 2000s and the late 2000s. Moreover, we can broadly characterise these periods as regimes in which correlations are rising or falling in strength and are moving between negative and positive average values. This, in turn, can be linked to changes in economic and market risks.

\section{Markov Regime Switching.}

The above analysis demonstrates the potential for switching behaviour, notably between periods of high and low correlations across the range of assets. Therefore, we examine whether the nature of the explanatory relations for the correlation series could be better described by a non-linear model. To this end, we extend the linear model of Section 3 and estimate a Markov switching model given by:

$$
z_{i j, t}=\mu_{s, t}+\sigma_{s, t} \varepsilon_{t}
$$

Where $z_{i j, t}$ is the logistic transform (equation (2)) of the correlation between assets $i$ and $j, \mu_{s, t}$ refers to the regime-dependent conditional mean series, which includes the same explanatory variables as for equation (1), $\sigma_{s, t}$ is the regime-dependent volatility series and $\varepsilon_{t}$ is the random error term, which is iid and normally distributed with a mean of zero and variance of one.

The regime variable, $s_{t}$ is assumed to follow a first-order Markov chain where the probability of being in one regime depends upon the previous state, with transition probabilities given by: $P_{(m n)}=P\left(s_{t}=m s_{t-1}=n\right)=p_{m n}$. These probabilities can be collected in a transition matrix, which, allowing for two regimes, is given by:

$$
\boldsymbol{P}=\left(\begin{array}{ll}
p_{00} & p_{10} \\
p_{01} & p_{11}
\end{array}\right)
$$

where the $m n$-th element represents the probability of transitioning from regime $n$ in period $t$ 1 to regime $m$ in period $t$. The two regimes thus refer to low and high correlation periods. 
Table 5(I-II) presents the estimated results. For ease of presentation, again, we only report the predictive coefficient results for the main, non-asset return, series, with the results for the remaining series available upon request. We can consider whether the explanatory variables consistently predict the correlations of given asset return series and if that differs across the two regimes of behaviour. In comparison to the linear model presented in Table 3, we can observe a greater level of significance, particularly across the term structure, the purchasing managers index and consumer sentiment. In the first regime, the term structure exhibits notable statistical significance (including up to the $10 \%$ level) across the range of correlations. Notably, it is significant for the majority of the correlations involving stock, bond, gold, REIT and dollar returns. In the second regime, the term structure is significant for the majority of the stock, corporate bond, commodity, gold, REIT and dollar return correlations. Across the two regimes, the term structure exhibits a similar level of significance, but notably, is more significant for government bonds in the first regime and corporate bonds in the second regime.

The purchasing managers index is significant in the majority of the correlation regressions for bonds, world stocks, commodities, gold and dollar returns in the first regime and for US and world stocks, government and corporate bonds, commodities, gold, REIT and dollar returns in the second regime. Thus, the PMI series shows more statistical significance in the second regime. Consumer sentiment is significant in the regressions involving stock, commodity, gold, REIT and dollar return correlations in the first regime. In the second regime, consumer sentiment is significant for US and world stocks, government and corporate bonds, commodity, REIT and dollar return correlations. Hence, as with the PMI series, there are more significant relations in the second regime for consumer sentiment.

For each of the term structure, PMI and consumer sentiment, there is also some evidence of a significant predictive relation for the correlations across the other asset return 
series and regimes, albeit for less than half of the regressions. Indeed, these series have predictive power for at least two and (more typically) three correlation regressions across all series and regimes. For the remaining explanatory variables, there is no substantial evidence of a significant predictive relation across the correlation series, although there is some support for the dividend-price ratio for bond and world stock return correlations. Equally, there is some supportive evidence that inflation contains predictive power for the correlations involving corporate bond, world stock, commodities, gold and dollar returns. But in each case, the significant relation is found in less than half of the correlation regressions. As with the linear regression, the change in both the short-term (3-month) interest rate and industrial production exhibit little predictive power for the correlations.

To further illustrate the nature of the results and the additional information that we can capture by examining the non-linear model, Figure 4 plots the one-year rolling correlation window for stock and bond returns together with the estimated probability of being in regime 1. Evident from this graph is that the Markov switching model separates the relation between the correlation series and the explanatory variables between positive and negative values of the correlation series. The relations identified in regime 1 thus relate to positive correlation values, while those in regime 2 relate to negative correlation values. Without discussing all 28 regressions in detail, we can see that broadly the same variables are significant across the two regimes and often differ in the strength of the coefficient, although there is no obvious pattern across the full set of correlations. Notwithstanding this, it is perhaps pertinent to note that both the indicators of confidence, PMI (for firms) and consumer sentiment (for households) exhibit greater significance when correlations are negative. This emphasises the key role played by expectations in driving asset price movements. In comparing the non-linear Markov switching model with the linear model of Table 3, we present in the final row of Table 5 the ratio of the Schwarz information criterion 
obtained from the non-linear to linear model. For the non-linear model to be preferred then this ratio would be less than one. As we can see for all correlation regressions, the Markov switching model is preferred over the linear model.

\section{Economic Implications.}

The above sets of results indicate that the movement in correlations across the eight assets examined here can be explained by economic variables, notably interest rates, inflation (to a lesser extent) and firm and household confidence, through the PMI and consumer sentiments measures. Furthermore, the results indicate that correlations between the assets cycle through periods of higher and lower values that appear related to changing risk. Given this, the information contained in the movements of the asset returns and their correlations may contain information concerning future economic conditions.

To examine this in a manageable fashion, given that across the eight assets there are 28 correlations, we form two portfolios, which we define as one that contains risky assets and one that contains safe assets. Specifically, we define the risky portfolio as an equally weighted portfolio of domestic US and world stocks, commodities and real estate investments, while the safe portfolio is an equally weighted portfolio of bonds (government and corporate), gold and the dollar. ${ }^{12}$ The choice over what constitutes safe and risky assets is based on a historical view as well as the characteristics of the assets reported in Table 1. Specifically, the risky assets exhibit a higher standard deviation and a more extreme spread between the maximum and minimum values (and a lower minimum value) in comparison to the safe assets. Purely on the basis of the summary statistics, gold would not appear to be a safe asset as it exhibits both a standard deviation and a minimum value equivalent to risky stocks; however, it is widely regarded as a safe haven asset as, unlike stocks, it acts as a store

\footnotetext{
${ }^{12}$ We also consider alternative portfolios, such as a risky one that only contains stocks or stocks and commodities and a safe portfolio that only contains government bonds and gold. The results across these alternatives broadly holds, although the strength of the findings does differ.
} 
of value. Baur and Lucey (2010) report that gold acts as a hedge and safe haven against stocks although not necessarily bonds, which perhaps supports the view that gold and bonds together can be regarded as safe assets.

Having defined the two portfolios, we examine the one-year moving correlation between these series, which is graphed in Figure 5. Here, a positive correlation implies that investors are buying both risky and safe assets, which would be consistent with optimistic investors and in the context of a diversified portfolio holding. In contrast, a negative correlation would imply that investors are buying one asset type and selling the other asset type. This would be consistent with a period of increased market risk in which investors are eschewing risky assets for safer ones. Equally, a negative correlation could arise when investors are highly confident and thus moving into risky assets at the expense of safe ones. To illustrate these possibilities, Figure 5 plots the risky/safe correlation against two dummy variables, one depicting NBER dated recessions and a second depicting bear markets, which are defined according to a three-year period where the US stock market falls. ${ }^{13}$ Evident in these graphs is that periods of recession and bear markets are generally accompanied by a negative correlation between the risky and safe portfolios as investors move assets in a flightto-safety approach. Moreover, there is some evidence that the movement in the correlation precedes the onset of a recession or bear market. Nonetheless, it can also be observed that there are periods of negative association that, by implication, are associated with a bull market and a period of economic expansion. Notably, this can be seen towards the end of the sample period, where the effects of quantitative easing have led to low bond yields, but also during the late-1980s and early-1990s period.

Therefore, we wish to examine whether the information contained in the safe and risky portfolios and their correlation have any economic content. To do this, we consider two

\footnotetext{
${ }^{13}$ This definition for a bear market follows Cooper et al (2004).
} 
perspectives, first, whether there is information beneficial to investors in building a portfolio and second, whether there is information beneficial to policy makers in regard of a leading indicator measure for subsequent economic conditions.

\section{Market Timing}

The evidence presented in Figure 5 suggests that the nature of the correlation between the risky and safe portfolios may be linked to market and economic performance. We first consider whether this correlation contains any information that may be useful in market timing decisions between assets. As such, we examine the performance of the risky and safe portfolios according to the sign of their correlation. Table 6 presents the Sharpe ratio (i.e., the portfolio return in excess of a 3-month Treasury bill divided by the standard deviation) for both the risky and safe portfolio according to whether the lagged correlation between them is either positive or negative. Evidently, we can observe that when the correlation is positive the Sharpe ratio for the risky portfolio is greater for than the Sharpe ratio for safe portfolio and is also greater than the Sharpe ratio for the risky portfolio when the correlation is negative. Equally, when the correlation is negative, the Sharpe ratio on the safe portfolio is greater than the Sharpe ratio for both the risky portfolio and the safe portfolio when the correlation is positive. This indicates the potential for an investor to time the market according to the correlation between the two portfolios.

To further consider whether the correlation contains information useful for investors we construct a simple trading rule based on the sign of the correlation. Specifically, if the lagged correlation is positive then we hold the risky portfolio, while if the lagged correlation is negative, we hold the safe portfolio. The Sharpe ratio results of applying the above trading rule is also presented in Table 6, together with three baseline passive portfolio holdings; holding the risky portfolio, the safe portfolio or a portfolio that is split $60 \% / 40 \%$ in favour of 
the risky portfolio. The results indicate that the risky only portfolio outperforms the safe only portfolio, while the $60 / 40$ portfolio marginally improves on the performance of the risky portfolio. The constructed trading portfolio based on the correlation outperforms all three passive portfolios with the Sharpe ratio increasing by around $50 \%$ in value and thus a noticeable improvement over the three passive portfolios.

However, the higher Sharpe ratio may simply be a reward for taking on higher risk that could equally be captured by holding a greater amount of a (diversified) stock portfolio. Therefore, to consider whether there is any extra gain over and above that which could be obtained through additional systematic risk, we estimate a regression of the portfolio returns on first, just the market portfolio (CAPM) and second the market portfolio and both the size and value premium (Fama-French Three-Factors, Fama and French, 1992, 1993). ${ }^{14}$ For comparison with the portfolio based on the lagged correlation, we also include the 60/40 portfolio. Both results are reported in the lower part of Table 6.

The results for the $60 / 40$ portfolio reveal that this portfolio is safer than the market portfolio with a beta of approximately 0.5. From the Fama-French factors, the portfolio also has a large firm bias (it contains $60 \%$ of S\&P500 firms) and while the value premium indicates a small value bias, it is not statistically significant. In terms of the alpha, which indicates whether there is any abnormal return to be gained through the portfolio, this is marginally significant in the CAPM regression but statistically insignificant in the threefactor model regression. Economically, the coefficient is also small. With respect to the portfolio constructed on the basis of the risky and safe correlation, it also has a beta less than one but now loads positively on the size premium, while the value premium is marginally significant and positive. For both the CAPM and three-factor regressions, the alpha (abnormal return) is both positive and statistically significant. Thus, in principle, the

\footnotetext{
${ }^{14}$ We obtain the data for the market portfolio, size and value premium from the website of Ken French: http://mba.tuck.dartmouth.edu/pages/faculty/ken.french/data_library.html.
} 
constructed portfolio based on the correlation between risky and safe assets can provide a return above that obtainable from expected systematic risk factors.

\section{Predicting Economic Activity}

To further examine the economic usefulness of the interrelation between the assets, we consider predictive regressions for measures of economic activity. In particular, we estimate the following model:

$$
y_{t+k}=\alpha_{0}+\Sigma_{i} \beta_{i} w_{t}+\varepsilon_{t+k}
$$

Where $y_{t+k}$ is a measure of economic activity for $k$-steps ahead, $w_{t}$ are the predictor variables and $\varepsilon_{t+k}$ is a random error term. Our measures of activity are the monthly change in industrial production and the consumer price index and their absolute values. We consider the absolute values as a measure of macroeconomic variability or risk. The explanatory variables are the return on the risky and safe portfolios as well as their time-varying correlation.

The regression results are presented in Table 7 and reveal an interesting pattern in the nature of the relations with the economic growth level series and their absolute value. Notably, across the time horizons, $k$, from one-month to one-year, we can see that the risky portfolio exhibits predictive power for the level of monthly industrial production growth and inflation. Moreover, the positive coefficient value suggests that an increase in the risky portfolio is consistent with an expanding economy. The safe portfolio exhibits a negative coefficient, which provides a consistent economic interpretation whereby investors move into safer assets when their expectations of future economic performance declines. However, it exhibits less statistical significance, being marginally significant at the one-month horizon and significant at the one-quarter horizon only. The correlation between the risky and safe portfolios has predictive power for the absolute value of monthly industrial production growth at the shorter two horizons and inflation at all horizons (including the $10 \%$ statistical 
significance level). Thus, the return series have predictive power for the growth levels, while the correlation has predictive power for the variability of the growth levels. Hence, the correlation series have predictive power for macroeconomic risk, which is consistent with the view expressed above that movement in asset return correlations are linked to risk.

Understanding this information may be of importance to policy makers in using financial market information in a leading indicator role.

\section{Summary and Conclusion.}

This paper examines the nature of the interrelations and correlations between eight financial assets. Existing research typically examines the behaviour of two or three assets (typically stocks, bonds and one other asset e.g., gold). By examining behaviour across eight assets it is hoped the results here will be of interest to both investors in building portfolios and policymakers as the movement of assets reflects investor perceptions of expected future macroeconomic conditions.

Our analysis focusses on one-year moving correlations between monthly observations of returns on US stocks, world (excluding US) stocks, US long-term government bonds, US BAA rated corporate bonds, commodities, gold, US real estate investment trust and the dollar over the period from 1980 to mid-2017. ${ }^{15}$ As the (time-varying) correlation is an unobservable variable, we construct it using a rolling window of one-year. ${ }^{16}$ Summary statistics for the constructed correlations reveals that each of the 28 correlations exhibit noticeable time-variation and all exhibit both positive and negative values.

We seek to explain the movements in the time-varying correlations using a range of macroeconomic and financial variables, including interest rates, the dividend-price ratio, inflation, output growth and measures of producer and consumer confidence. The results

\footnotetext{
${ }^{15}$ The data sample begins in 1975, with the first five years of the data used in the construction of correlations.

${ }^{16}$ Results obtained using a five-year rolling window and the DCC-GARCH model are comparable and available upon request.
} 
from a linear regression analysis reveal that certain explanatory variables feature prominently in the correlations for given assets. The term structure of interest rates exhibits predictive power for the majority of gold return correlations, while changes in the dividend-price ratio and inflation heavily affect bond return correlations. Commodity return correlations are explained by movements in producer and consumer confidence, the latter also explaining stock, real estate and dollar return correlations. These results have intuitive appeal. Notably, changes in the term structure reflect changing economic conditions, from which investors will move between safer assets (gold) and other, speculative, assets. Changes in the dividendprice ratio will reflect changes in stock market valuation and thus may impact investor appetite for bonds. Equally, changes in inflation will have implications for the future course of the economy and thus investor decisions between stocks and bonds as safer and riskier assets in a portfolio. Changes in producer and consumer confidence will equally have implications for the economic outlook and the demand for goods and thus commodities, housing and the stock market.

Notwithstanding these results, there is the potential for breaks to exist within the relation between the correlations and the explanatory variables. Specific structural break tests support several breaks through the sample period, notably occurring around periods of economic recession as well as finance-based events, such as the dotcom bubble and crash. An examination of the time-varying correlations, including the use of a Markov-switching model, suggest a cycling between periods of high and low risk related correlations. We also observe some differences in predictive power across regimes of positive and negative correlations, with the sentiment measures more significant when correlations are negative.

A key issue that arises is whether there is information contained in the time-varying correlations that is economically useful for investors or policy-makers. To consider this issue in a tractable manner, we construct two portfolios, a safe and risky portfolio and consider the 
nature of their time-varying correlation. Our interest here lies, notably, in whether we can use the information contained in these portfolios and their interrelation to improve portfolio construction and whether they exhibit a leading indicator role for the economy. The results are supportive, with the correlation allowing switching between the safe and risky portfolios in such a way as to improve portfolio Sharpe ratios. Further, the safe and risky portfolio returns have predictive power for subsequent economic activity (output and inflation), while their correlation exhibits predictive power for the variability of economic activity.

Overall, it is hoped the results here provide information for investors and policymakers as well as academics seeking to understand the interrelations between assets as well as between financial and real markets. The results reveal that particular macroeconomic and financial variables are key drivers of the movements between asset returns, while the returns and movements of assets characterised as safe and risky contain information for both improving portfolio construction and predicting future economic conditions. 


\section{References}

Andersson M., Krylova, E,. \& Vähämaa, S. (2008). Why does the correlation between stock and bond returns vary over time? Applied Financial Economics, 18, 139-151.

Aslanidis, N., \& Christiansen, C. (2012). Smooth transition patterns in the realized stockbond correlation. Journal of Empirical Finance, 19, 454-464.

Aslanidis, N., \& Christiansen, C. (2014). Quantiles of the realized stock-bond correlation and links to the macroeconomy. Journal of Empirical Finance, 28, 321-331.

Aslanidis, N., Christiansen, C., \& Cipollini, A. (2019). Predicting bonds betas using macrofinance variables. Finance Research Letters, (forthcoming).

Baele, L., Bekaert, G., \& Inghelbrecht, K. (2010). The determinants of stock and bond return comovements. Review of Financial Studies, 23, 2374-2428.

Bai, J., \& Perron, P. (1998). Estimating and testing linear models with multiple structural changes. Econometrica, 66, 47-78.

Bai, J., \& Perron, P. (2003a). Computation and analysis of multiple structural change models. Journal of Applied Econometrics, 18, 1-22.

Bai, J., \& Perron, P. (2003b). Critical values for multiple structural change tests. Econometrics Journal, 6, 72-78.

Bakshi, G., Panayotov, G., \& Skoulakis, G. (2011). The Baltic dry index as a predictor of global stock returns, commodity returns and global economic activity. Working Paper available at SSRN: http://ssrn.com/abstract=1747345.

Barsky, R. (1989). Why don't the prices of stocks and bonds move together? American Economic Review, 79, 1132-1145.

Basak, S., \& Pavlova, A. (2016). A model of financialization of commodities. Journal of Finance, 71, 1511-1556.

Baur, D. (2010). Stock-bond co-movements and cross-country linkages. International Journal of Banking, Accounting and Finance, 2, 111-129.

Baur, D., \& Lucey, B. (2010). Is gold a hedge or a safe haven? An analysis of stocks, bonds and gold. Finance Review, 45, 217-229.

Black, A. J., Klinkowska, O., McMillan, D. G., \& McMillan, F. J. (2014). Forecasting stock returns: Do commodity prices help? Journal of Forecasting, 33, 627-639.

Campbell, J. Y., \& Ammer, J. (1993). What moves the stock and bond markets? A variance decomposition for long-term asset returns. Journal of Finance, 48, 3-37.

Campbell, J. Y., Sunderam, A., \& Viceira, L. M. (2017). Inflation bets or deflation hedges? The changing risks of nominal bonds. Critical Finance Review, 6, 263-301. 
Cheng, I-H., \& Xiong, W. (2013). The financialization of commodity markets. NBER Working Paper No. 19642.

Colacito. R., Engle., R., \& Ghysels, E. (2011). A component model for dynamic correlations. Journal of Econometrics, 164, 45-59.

Connolly, R., Stivers, C., \& Sun, L. (2005). Stock market uncertainty and the stock-bond return relation. Journal of Financial and Quantitative Analysis, 40, 161-194.

Connolly, R., Stivers, C., \& Sun, L. (2007). Commonality in the time variation of stock-bond and stock-stock return comovements. Journal of Financial Markets, 10, 192-218.

Cooper, M., Gutierrez Jr, R., \& Hameed, A. (2004). Market states and momentum. Journal of Finance, 59, 1345-1365.

Creti, A., Joëts, M., \& Mignon, V. (2013). On the links between stock and commodity markets' volatility. Energy Economics, 37, 16-28.

Engle, R. (2002). Dynamic conditional correlation - a simple class of multivariate GARCH models. Journal of Business and Economic Statistics, 20, 339-350.

Estrella, A., \& Hardouvelis, G. A. (1992). The term structure as a predictor of real economic activity. Journal of Finance, 46, 555-576.

Falkowski, M. (2011). Financialization of commodities. Contemporary Economics, 5, 4-17.

Fama, E. F., \& French, K. R. (1992). The cross-section of expected returns. Journal of Finance, 47, 427-465.

Fama, E. F., \& French, K. R. (1993). Common risk factors in the returns on stocks and bonds. Journal of Financial Economics, 33, 3-56.

Fan, J., \& Mitchell, M. (2017). Equity-bond correlation: A historical perspective. Graeme Capital Management Research Note, September, 1-3.

Gulko, L. (2002). Decoupling. Journal of Portfolio Management, 28, 59-66.

Hardouvelis, G. A. (1994). The term structure spread and future changes in long and short rates in the G7 countries. Journal of Monetary Economics, 33, 255-283.

Henry, O. T., Olekalns, N., \& Thong, J. (2004). Do stock market returns predict changes to output? Evidence from a nonlinear panel data model. Empirical Economics, 29, 527-540.

Humpe, A., \& McMillan, D. G. (2016). Equity-bond returns correlation and the bond yield: Evidence of switching behaviour from the G7 markets. Credit and Capital Markets, 49, 415444.

Jacobsen, B., Marshall, B. R., \& Visaltanachoti, N. (2013). Stock market predictability and industrial metal returns. Working Paper available at SSRN:

http://ssrn.com/abstract=1660864. 
Lange, R. H. (2018). The predictive content of the term premium for GDP growth in Canada: Evidence from linear, Markov-switching and probit estimations. North American Journal of Economics and Finance, 44, 80-91.

Li, L. (2002). Macroeconomic factors and the correlation of stock and bond returns. Yale International Center for Finance Working Paper, No 02-46.

Mamaysky, H. (2002). Market prices of risk and return predictability in a joint stock-bond pricing model. Yale ICF Working Paper No. 02-25.

McAleer, M., \& Medeiros, M. C. (2008). Realized volatility: A review. Econometric Reviews, 27, 10-45.

Ohmi, H., \& Okimoto, T. (2016). Trends in stock-bond correlations. Applied Economics, 48, $536-552$

Olson, E., Vivian A., \& Wohar, M. E. (2014). The relationship between energy and equity markets: Evidence from volatility impulse response functions. Energy Economics, 43, 297305.

Rankin, E., \& Shah Idil, M. (2014). A century of stock-bond correlations. Reserve Bank of Australia Bulletin, September, 67-74.

Schwert, G. W. (1990). Stock returns and real activity: A century of evidence. Journal of Finance, 45, 1237-1257.

Shiller, R. J., \& Beltratti, A. E. (1992). Stock prices and bond yields: Can their comovements be explained in terms of present value models? Journal of Monetary Economics, 30, 25-46.

Stock, J. H., \& Watson, M. W. (1990). Business cycle fluctuations in US economic time series, 1959-1988. NBER Working Paper No. 3376.

Tang, K., \& Xiong, W. (2012). Index investing and the financialization of commodities. Financial Analysts Journal, 68, 54-74.

Venetis, I., Paya, I., \& Peel, D. (2007). Re-examination of the predictability of economic activity using the yield spread: A nonlinear approach. International Review of Economics and Finance, 12, 187-206.

Viceira, L. M. (2012). Bond risk, bond return volatility, and the term structure of interest rates. International Journal of Forecasting, 28, 97-117.

Vivian, A., \& Wohar, M. E. (2012). Commodity volatility breaks. Journal of International Financial Markets, Institutions and Money, 22, 395-422. 
Table 1. Summary Statistics for Asset Returns

\begin{tabular}{|c|c|c|c|c|c|c|c|}
\hline & Mean & Median & Min & Max & SD & Skew & Kurt \\
\hline SP & 0.692 & 1.053 & -24.542 & 12.378 & 4.339 & -0.917 & 6.344 \\
\hline $\mathrm{BD}$ & .647 & 0.530 & -8.243 & 11.944 & 2.468 & 0.291 & 4.548 \\
\hline BAA & 0.075 & 0.047 & -13.357 & 11.895 & 2.127 & -0.131 & 9.986 \\
\hline WRD & 0.511 & 0.864 & -23.409 & 13.495 & 4.950 & -0.659 & 4.521 \\
\hline $\mathrm{COM}$ & 256 & 0.429 & -33.127 & 20.653 & 5.670 & -0.580 & 6.054 \\
\hline GD & 0.197 & 0.063 & -25.322 & 24.325 & 5.160 & -0.038 & 6.443 \\
\hline REIT & 0.905 & 1.106 & -39.132 & 28.410 & 5.355 & -1.494 & 14.250 \\
\hline DOL & -0.012 & 0.058 & -6.795 & 8.342 & 2.137 & 0.078 & 3.337 \\
\hline \multicolumn{8}{|c|}{$\begin{array}{l}\text { Notes: Series are the first-difference of the S\&P500 index (SP), 10-year Treasury bond } \\
\text { index (BD), BAA-rated corporate bond index (BAA), world stock market index excluding } \\
\text { the US (WRD), the general GSCI commodity index (COM), gold price (GD), real estate } \\
\text { investment trust index (REIT) and the US dollar index (DOL). The entries refer to the } \\
\text { mean, median, minimum (Min), maximum (Max), standard deviation (SD), skewness } \\
\text { (Skew) and kurtosis (Kurt) values. }\end{array}$} \\
\hline
\end{tabular}


Table 2. Summary Statistics for Time-Varying Correlations

\begin{tabular}{|l|l|l|l|l|l|l|l|}
\hline & Mean & Median & Min & Max & SD & Skew & Kurt \\
\hline SP-BD & 0.065 & 0.110 & -0.849 & 0.863 & 0.471 & -0.210 & 1.875 \\
\hline SP-BAA & 0.050 & 0.065 & -0.661 & 0.691 & 0.273 & -0.114 & 2.35 \\
\hline SP-WRD & 0.654 & 0.709 & -0.420 & 0.971 & 0.261 & -1.123 & 4.020 \\
\hline SP-COM & 0.130 & 0.122 & -0.743 & 0.959 & 0.380 & 0.119 & 2.560 \\
\hline SP-GD & -0.026 & -0.059 & -0.756 & 0.753 & 0.339 & 0.265 & 2.311 \\
\hline SP-REIT & 0.539 & 0.579 & -0.275 & 0.981 & 0.276 & -0.606 & 2.701 \\
\hline SP-DOL & -0.172 & -0.155 & -0.915 & 0.774 & 0.361 & -0.063 & 2.197 \\
\hline BD-BAA & -0.010 & -0.003 & -0.725 & 0.678 & 0.253 & -0.215 & 3.01 \\
\hline BD-WRD & -0.001 & 0.049 & -0.837 & 0.850 & 0.413 & -0.122 & 1.930 \\
\hline BD-COM & -0.114 & -0.155 & -0.771 & 0.666 & 0.337 & 0.225 & 2.113 \\
\hline BD-GD & 0.058 & 0.103 & -0.751 & 0.898 & 0.330 & -0.095 & 2.459 \\
\hline BD-REIT & 0.144 & 0.128 & -0.814 & 0.838 & 0.382 & -0.130 & 2.160 \\
\hline BD-DOL & -0.140 & -0.135 & -0.873 & 0.734 & 0.354 & 0.019 & 2.303 \\
\hline $\begin{array}{l}\text { BAA- } \\
\text { WRD }\end{array}$ & 0.121 & 0.142 & -0.759 & 0.21 & 0.296 & -0.243 & 2.83 \\
\hline $\begin{array}{l}\text { BAA- } \\
\text { COM }\end{array}$ & -0.046 & -0.049 & -0.863 & 0.793 & 0.357 & -0.003 & 2.188 \\
\hline BAA-GD & 0.056 & 0.062 & -0.742 & 0.706 & 0.275 & -0.196 & 2.651 \\
\hline $\begin{array}{l}\text { BAA- } \\
\text { REIT }\end{array}$ & 0.152 & 0.192 & -0.677 & 0.750 & 0.327 & -0.277 & 2.162 \\
\hline $\begin{array}{l}\text { BAA- } \\
\text { DOL }\end{array}$ & -0.139 & -0.158 & -0.761 & 0.664 & 0.284 & 0.230 & 2.511 \\
\hline $\begin{array}{l}\text { WRD- } \\
\text { COM }\end{array}$ & 0.296 & 0.334 & -0.664 & 0.923 & 0.367 & -0.348 & 2.456 \\
\hline WRD-GD & 0.181 & 0.200 & -0.803 & 0.857 & 0.319 & -0.281 & 2.774 \\
\hline $\begin{array}{l}\text { WRD- } \\
\text { REIT }\end{array}$ & 0.399 & 0.416 & -0.473 & 0.937 & 0.304 & -0.544 & 2.832 \\
\hline $\begin{array}{l}\text { WRD- } \\
\text { DOL }\end{array}$ & -0.550 & -0.602 & -0.951 & 0.433 & 0.279 & 0.725 & 2.973 \\
\hline COM-GD & 0.227 & 0.254 & -0.598 & 0.833 & 0.339 & -0.347 & 2.323 \\
\hline $\begin{array}{l}\text { COM- } \\
\text { REIT }\end{array}$ & 0.057 & 0.025 & -0.810 & 0.898 & 0.400 & 0.017 & 2.190 \\
\hline $\begin{array}{l}\text { COM- } \\
\text { DOL }\end{array}$ & -0.295 & -0.310 & -0.920 & 0.667 & 0.341 & 0.364 & 2.453 \\
\hline GD-REIT & 0.028 & 0.026 & -0.597 & 0.784 & 0.324 & 0.251 & 2.345 \\
\hline GD-DOL & -0.357 & -0.434 & -0.877 & 0.608 & 0.313 & 0.745 & 2.887 \\
\hline $\begin{array}{l}\text { REIT- } \\
\text { DOL }\end{array}$ & -0.123 & -0.105 & -0.847 & 0.714 & 0.372 & 0.024 & 2.262 \\
\hline Notes: Series names and statistics are the same as for Table 1. & & & \\
\hline
\end{tabular}


Table 3. Time-Varying Correlation Linear Regression Results

\begin{tabular}{|c|c|c|c|c|c|c|c|c|c|c|c|c|c|c|c|}
\hline & SP-BD & $\begin{array}{l}\text { SP- } \\
\text { BAA }\end{array}$ & $\begin{array}{l}\text { SP- } \\
\text { WRD }\end{array}$ & $\begin{array}{l}\text { SP- } \\
\text { COM }\end{array}$ & SP-GD & $\begin{array}{l}\text { SP- } \\
\text { REIT }\end{array}$ & $\begin{array}{l}\text { SP- } \\
\text { DOL }\end{array}$ & $\begin{array}{l}\text { BD- } \\
\text { BAA }\end{array}$ & $\begin{array}{l}\text { BD- } \\
\text { WRD }\end{array}$ & $\begin{array}{l}\text { BD- } \\
\text { COM }\end{array}$ & $\begin{array}{l}\text { BD- } \\
\text { GD } \\
\end{array}$ & $\begin{array}{l}\text { BD- } \\
\text { REIT }\end{array}$ & $\begin{array}{l}\text { BD- } \\
\text { DOL }\end{array}$ & & \\
\hline Cnst & $\begin{array}{l}0.066 \\
(0.14) \\
\end{array}$ & $\begin{array}{l}0.213 \\
(1.17) \\
\end{array}$ & $\begin{array}{l}0.739 \\
(3.77) \\
\end{array}$ & $\begin{array}{l}0.680 \\
(1.65) \\
\end{array}$ & $\begin{array}{l}0.782 \\
(2.19) \\
\end{array}$ & $\begin{array}{l}1.447 \\
(7.45) \\
\end{array}$ & $\begin{array}{l}-1.080 \\
(-3.53)\end{array}$ & $\begin{array}{l}-0.360 \\
(-1.58)\end{array}$ & $\begin{array}{l}-0.018 \\
(-0.04)\end{array}$ & $\begin{array}{l}-0.178 \\
(-0.62)\end{array}$ & $\begin{array}{l}0.459 \\
(1.54)\end{array}$ & $\begin{array}{l}-0.148 \\
(-0.40)\end{array}$ & $\begin{array}{l}-0.491 \\
(-1.36)\end{array}$ & & \\
\hline $3 \mathrm{~m}-\mathrm{TB}$ & $\begin{array}{l}0.041 \\
(0.84) \\
\end{array}$ & $\begin{array}{l}0.025 \\
(0.69) \\
\end{array}$ & $\begin{array}{l}-0.023 \\
(-0.73)\end{array}$ & $\begin{array}{l}-0.010 \\
(-0.21)\end{array}$ & $\begin{array}{l}-0.032 \\
(-0.73)\end{array}$ & $\begin{array}{l}0.044 \\
(1.93)\end{array}$ & $\begin{array}{l}0.013 \\
(0.95) \\
\end{array}$ & $\begin{array}{l}-0.028 \\
(-0.98)\end{array}$ & $\begin{array}{l}0.003 \\
(0.06)\end{array}$ & $\begin{array}{l}-0.012 \\
(-0.34)\end{array}$ & $\begin{array}{l}-0.013 \\
(-0.42)\end{array}$ & $\begin{array}{l}-0.014 \\
(-0.36)\end{array}$ & $\begin{array}{l}0.026 \\
(0.61) \\
\end{array}$ & & \\
\hline $\mathrm{TS}$ & $\begin{array}{l}0.031 \\
(0.83) \\
\end{array}$ & $\begin{array}{l}-0.053 \\
(-2.34)\end{array}$ & $\begin{array}{l}-0.013 \\
(-0.57) \\
\end{array}$ & $\begin{array}{l}-0.018 \\
(-0.59)\end{array}$ & $\begin{array}{l}-0.065 \\
(-2.65)\end{array}$ & $\begin{array}{l}0.001 \\
(0.03) \\
\end{array}$ & $\begin{array}{l}0.043 \\
(1.68) \\
\end{array}$ & $\begin{array}{l}0.001 \\
(0.01) \\
\end{array}$ & $\begin{array}{l}0.047 \\
(1.44) \\
\end{array}$ & $\begin{array}{l}-0.028 \\
(-1.02)\end{array}$ & $\begin{array}{l}-0.001 \\
(-0.02) \\
\end{array}$ & $\begin{array}{l}0.036 \\
(1.12) \\
\end{array}$ & $\begin{array}{l}-0.036 \\
(-1.15)\end{array}$ & & \\
\hline DP & $\begin{array}{l}-2.820 \\
(-3.19)\end{array}$ & $\begin{array}{l}0.052 \\
(0.07) \\
\end{array}$ & $\begin{array}{l}0.150 \\
(0.20) \\
\end{array}$ & $\begin{array}{l}-0.663 \\
(-0.59)\end{array}$ & $\begin{array}{l}0.927 \\
(1.14) \\
\end{array}$ & $\begin{array}{l}0.925 \\
(1.28) \\
\end{array}$ & $\begin{array}{l}0.382 \\
(0.33) \\
\end{array}$ & $\begin{array}{l}1.482 \\
(1.33) \\
\end{array}$ & $\begin{array}{l}-2.457 \\
(-2.88) \\
\end{array}$ & $\begin{array}{l}-2.354 \\
(-3.16)\end{array}$ & $\begin{array}{l}-0.344 \\
(-0.41) \\
\end{array}$ & $\begin{array}{l}1.118 \\
(1.05) \\
\end{array}$ & $\begin{array}{l}2.637 \\
(2.48) \\
\end{array}$ & & \\
\hline Infl & $\begin{array}{l}24.403 \\
(3.52)\end{array}$ & $\begin{array}{l}-3.244 \\
(-0.60)\end{array}$ & $\begin{array}{l}-13.57 \\
(-3.00)\end{array}$ & $\begin{array}{l}-2.440 \\
(-0.36)\end{array}$ & $\begin{array}{l}0.055 \\
(0.01)\end{array}$ & $\begin{array}{l}2.964 \\
(0.79)\end{array}$ & $\begin{array}{l}11.834 \\
(1.93)\end{array}$ & $\begin{array}{l}8.523 \\
(2.05)\end{array}$ & $\begin{array}{l}20.407 \\
(2.99)\end{array}$ & $\begin{array}{l}6.217 \\
(1.20)\end{array}$ & $\begin{array}{l}-10.60 \\
(-1.97)\end{array}$ & $\begin{array}{l}9.259 \\
(1.37)\end{array}$ & $\begin{array}{l}-19.38 \\
(-3.08)\end{array}$ & & \\
\hline IP & $\begin{array}{l}8.474 \\
(2.28) \\
\end{array}$ & $\begin{array}{l}-2.542 \\
(-1.04)\end{array}$ & $\begin{array}{l}-5.299 \\
(-2.79)\end{array}$ & $\begin{array}{l}-2.475 \\
(-0.76)\end{array}$ & $\begin{array}{l}4.408 \\
(1.45) \\
\end{array}$ & $\begin{array}{l}2.548 \\
(1.11)\end{array}$ & $\begin{array}{l}4.163 \\
(1.34) \\
\end{array}$ & $\begin{array}{l}1.917 \\
(0.63) \\
\end{array}$ & $\begin{array}{l}2.802 \\
(0.87)\end{array}$ & $\begin{array}{l}2.631 \\
(1.01) \\
\end{array}$ & $\begin{array}{l}-3.607 \\
(-1.31)\end{array}$ & $\begin{array}{l}0.281 \\
(0.09) \\
\end{array}$ & $\begin{array}{l}-2.411 \\
(-0.69)\end{array}$ & & \\
\hline PMI & $\begin{array}{l}-0.020 \\
(-2.00)\end{array}$ & $\begin{array}{l}0.003 \\
(0.07) \\
\end{array}$ & $\begin{array}{l}0.005 \\
(1.31) \\
\end{array}$ & $\begin{array}{l}0.014 \\
(1.85) \\
\end{array}$ & $\begin{array}{l}-0.001 \\
(-0.16)\end{array}$ & $\begin{array}{l}0.001 \\
(0.20)\end{array}$ & $\begin{array}{l}-0.009 \\
(-1.55)\end{array}$ & $\begin{array}{l}0.005 \\
(1.11)\end{array}$ & $\begin{array}{l}-0.012 \\
(-1.39)\end{array}$ & $\begin{array}{l}-0.016 \\
(-2.84)\end{array}$ & $\begin{array}{l}-0.002 \\
(-0.38)\end{array}$ & $\begin{array}{l}-0.007 \\
(-0.81)\end{array}$ & $\begin{array}{l}0.009 \\
(1.31) \\
\end{array}$ & & \\
\hline CS & $\begin{array}{l}0.010 \\
(2.73) \\
\end{array}$ & $\begin{array}{l}-0.002 \\
(-0.74) \\
\end{array}$ & $\begin{array}{l}-0.003 \\
(-1.54) \\
\end{array}$ & $\begin{array}{l}-0.014 \\
(-4.63) \\
\end{array}$ & $\begin{array}{l}-0.008 \\
(-2.83) \\
\end{array}$ & $\begin{array}{l}-0.011 \\
(-5.21) \\
\end{array}$ & $\begin{array}{l}0.015 \\
(5.11) \\
\end{array}$ & $\begin{array}{l}0.001 \\
(0.31) \\
\end{array}$ & $\begin{array}{l}0.006 \\
(1.65) \\
\end{array}$ & $\begin{array}{l}0.011 \\
(4.83) \\
\end{array}$ & $\begin{array}{l}-0.003 \\
(-1.10) \\
\end{array}$ & $\begin{array}{l}0.006 \\
(1.83) \\
\end{array}$ & $\begin{array}{l}0.001 \\
(0.02) \\
\end{array}$ & & \\
\hline \multirow[t]{2}{*}{ R-sq. } & 0.133 & 0.061 & 0.095 & 0.193 & 0.120 & 0.264 & 0.235 & 0.065 & 0.072 & 0.206 & 0.057 & 0.062 & 0.084 & & \\
\hline & $\begin{array}{l}\text { BAA- } \\
\text { WRD }\end{array}$ & $\begin{array}{l}\text { BAA- } \\
\text { COM }\end{array}$ & $\begin{array}{l}\text { BAA- } \\
\text { GD }\end{array}$ & $\begin{array}{l}\text { BAA- } \\
\text { REIT }\end{array}$ & $\begin{array}{l}\text { BAA- } \\
\text { DOL }\end{array}$ & $\begin{array}{l}\text { WRD- } \\
\text { COM }\end{array}$ & $\begin{array}{l}\text { WRD- } \\
\text { GD }\end{array}$ & $\begin{array}{l}\text { WRD- } \\
\text { REIT }\end{array}$ & $\begin{array}{l}\text { WRD- } \\
\text { DOL }\end{array}$ & $\begin{array}{l}\text { COM- } \\
\text { GD }\end{array}$ & $\begin{array}{l}\text { COM- } \\
\text { REIT }\end{array}$ & $\begin{array}{l}\text { COM- } \\
\text { DOL }\end{array}$ & $\begin{array}{l}\text { GD- } \\
\text { REIT }\end{array}$ & $\begin{array}{l}\text { GD- } \\
\text { DOL }\end{array}$ & $\begin{array}{l}\text { REIT- } \\
\text { DOL }\end{array}$ \\
\hline Cnst & $\begin{array}{l}0.130 \\
(0.48) \\
\end{array}$ & $\begin{array}{l}-0.170 \\
(-0.41) \\
\end{array}$ & $\begin{array}{l}0.079 \\
(0.26) \\
\end{array}$ & $\begin{array}{l}0.779 \\
(2.84) \\
\end{array}$ & $\begin{array}{l}-0.001 \\
(-0.01) \\
\end{array}$ & $\begin{array}{l}0.453 \\
(0.96) \\
\end{array}$ & $\begin{array}{l}0.494 \\
(1.43) \\
\end{array}$ & $\begin{array}{l}1.040 \\
(4.80) \\
\end{array}$ & $\begin{array}{l}-1.257 \\
(-5.93) \\
\end{array}$ & $\begin{array}{l}1.075 \\
(3.68) \\
\end{array}$ & $\begin{array}{l}0.433 \\
(0.93) \\
\end{array}$ & $\begin{array}{l}-0.903 \\
(-2.17) \\
\end{array}$ & $\begin{array}{l}0.002 \\
(0.01) \\
\end{array}$ & $\begin{array}{l}-0.999 \\
(-3.60) \\
\end{array}$ & $\begin{array}{c}-0.816 \\
(-2.36) \\
\end{array}$ \\
\hline $3 \mathrm{~m}-\mathrm{TB}$ & $\begin{array}{l}0.005 \\
(0.14) \\
\end{array}$ & $\begin{array}{l}0.027 \\
(0.47) \\
\end{array}$ & $\begin{array}{l}-0.007 \\
(-0.17) \\
\end{array}$ & $\begin{array}{l}0.080 \\
(2.39) \\
\end{array}$ & $\begin{array}{l}-0.018 \\
(-0.44) \\
\end{array}$ & $\begin{array}{l}0.021 \\
(0.44) \\
\end{array}$ & $\begin{array}{l}-0.001 \\
(-0.01) \\
\end{array}$ & $\begin{array}{l}0.009 \\
(0.27) \\
\end{array}$ & $\begin{array}{l}-0.012 \\
(-0.51) \\
\end{array}$ & $\begin{array}{l}-0.038 \\
(-0.94) \\
\end{array}$ & $\begin{array}{l}0.014 \\
(0.25) \\
\end{array}$ & $\begin{array}{l}0.021 \\
(0.50) \\
\end{array}$ & $\begin{array}{l}-0.026 \\
(-0.53) \\
\end{array}$ & $\begin{array}{l}-0.019 \\
(-0.63) \\
\end{array}$ & $\begin{array}{l}0.003 \\
(0.07) \\
\end{array}$ \\
\hline $\mathrm{TS}$ & $\begin{array}{l}-0.052 \\
(-2.21) \\
\end{array}$ & $\begin{array}{l}-0.008 \\
(-0.28) \\
\end{array}$ & $\begin{array}{l}-0.045 \\
(-1.71) \\
\end{array}$ & $\begin{array}{l}0.037 \\
(1.41) \\
\end{array}$ & $\begin{array}{l}-0.011 \\
(-0.41) \\
\end{array}$ & $\begin{array}{l}-0.021 \\
(-0.72) \\
\end{array}$ & $\begin{array}{l}-0.109 \\
(-3.98) \\
\end{array}$ & $\begin{array}{l}0.016 \\
(0.70) \\
\end{array}$ & $\begin{array}{l}0.021 \\
(1.02) \\
\end{array}$ & $\begin{array}{l}-0.077 \\
(-2.61) \\
\end{array}$ & $\begin{array}{l}-0.008 \\
(-0.24) \\
\end{array}$ & $\begin{array}{l}0.070 \\
(2.61) \\
\end{array}$ & $\begin{array}{l}-0.039 \\
(-1.49) \\
\end{array}$ & $\begin{array}{l}-0.070 \\
(3.00) \\
\end{array}$ & $\begin{array}{c}-0.012 \\
(-0.41) \\
\end{array}$ \\
\hline DP & $\begin{array}{l}-0.328 \\
(-0.40)\end{array}$ & $\begin{array}{l}-0.530 \\
(-0.48)\end{array}$ & $\begin{array}{l}0.655 \\
(0.89)\end{array}$ & $\begin{array}{l}-3.035 \\
(-3.56)\end{array}$ & $\begin{array}{l}0.885 \\
(1.06) \\
\end{array}$ & $\begin{array}{l}-0.948 \\
(-0.98)\end{array}$ & $\begin{array}{l}1.221 \\
(1.65)\end{array}$ & $\begin{array}{l}0.889 \\
(1.15) \\
\end{array}$ & $\begin{array}{l}0.087 \\
(0.12) \\
\end{array}$ & $\begin{array}{l}0.935 \\
(1.28)\end{array}$ & $\begin{array}{l}-0.382 \\
(-0.33)\end{array}$ & $\begin{array}{l}0.424 \\
(0.45) \\
\end{array}$ & $\begin{array}{l}1.226 \\
(1.30)\end{array}$ & $\begin{array}{l}-0.487 \\
(-0.59)\end{array}$ & $\begin{array}{c}-0.183 \\
(-0.17)\end{array}$ \\
\hline Infl & $\begin{array}{l}3.654 \\
(0.69) \\
\end{array}$ & $\begin{array}{l}-8.485 \\
(-1.29)\end{array}$ & $\begin{array}{l}-4.507 \\
(-0.78) \\
\end{array}$ & $\begin{array}{l}14.155 \\
(1.95)\end{array}$ & $\begin{array}{l}-7.404 \\
(-1.31) \\
\end{array}$ & $\begin{array}{l}-3.856 \\
(-0.61) \\
\end{array}$ & $\begin{array}{l}5.327 \\
(0.89) \\
\end{array}$ & $\begin{array}{l}-3.006 \\
(-0.67) \\
\end{array}$ & $\begin{array}{l}-0.183 \\
(-0.05)\end{array}$ & $\begin{array}{l}3.569 \\
(0.63) \\
\end{array}$ & $\begin{array}{l}1.919 \\
(0.24) \\
\end{array}$ & $\begin{array}{l}18.194 \\
(3.18)\end{array}$ & $\begin{array}{l}-8.008 \\
(-1.22)\end{array}$ & $\begin{array}{l}1.001 \\
(0.20) \\
\end{array}$ & $\begin{array}{l}9.149 \\
(1.33) \\
\end{array}$ \\
\hline IP & -5.302 & -6.428 & -0.640 & 5.281 & 1.679 & -2.474 & 0.665 & 0.999 & 0.463 & -2.649 & 5.772 & 2.995 & -0.805 & 4.160 & 0.900 \\
\hline
\end{tabular}




\begin{tabular}{|c|c|c|c|c|c|c|c|c|c|c|c|c|c|c|c|}
\hline & $(-2.17)$ & $(-2.15)$ & $(-0.20)$ & $(1.68)$ & $(0.54)$ & $(-0.75)$ & $(0.25)$ & $(0.44)$ & $(0.22)$ & $(-0.93)$ & $(1.39)$ & $(1.17)$ & $(-0.25)$ & $(1.38)$ & $(0.31)$ \\
\hline PMI & $\begin{array}{l}0.006 \\
(1.10)\end{array}$ & $\begin{array}{l}0.013 \\
(1.68)\end{array}$ & $\begin{array}{l}0.008 \\
(1.41)\end{array}$ & $\begin{array}{l}-0.016 \\
(-2.93)\end{array}$ & $\begin{array}{l}0.004 \\
(0.80)\end{array}$ & $\begin{array}{l}0.016 \\
(1.86)\end{array}$ & $\begin{array}{l}0.002 \\
(0.31)\end{array}$ & $\begin{array}{l}0.008 \\
(1.98)\end{array}$ & $\begin{array}{l}-0.006 \\
(-1.21)\end{array}$ & $\begin{array}{l}-0.001 \\
(-0.22)\end{array}$ & $\begin{array}{l}0.011 \\
(1.25)\end{array}$ & $\begin{array}{l}-0.006 \\
(-0.75)\end{array}$ & $\begin{array}{l}0.005 \\
(0.68)\end{array}$ & $\begin{array}{l}0.007 \\
(1.06)\end{array}$ & $\begin{array}{l}-0.010 \\
(-1.55)\end{array}$ \\
\hline CS & $\begin{array}{l}-0.003 \\
(-0.90)\end{array}$ & $\begin{array}{l}-0.006 \\
(-1.76)\end{array}$ & $\begin{array}{c}-0.004 \\
(-1.77) \\
\end{array}$ & $\begin{array}{l}0.001 \\
(0.30)\end{array}$ & $\begin{array}{l}-0.004 \\
(-0.80)\end{array}$ & $\begin{array}{l}-0.011 \\
(-3.77)\end{array}$ & $\begin{array}{l}-0.003 \\
(-1.16)\end{array}$ & $\begin{array}{l}-0.013 \\
(-5.48)\end{array}$ & $\begin{array}{l}0.011 \\
(5.64)\end{array}$ & $\begin{array}{l}-0.007 \\
(-2.74)\end{array}$ & $\begin{array}{l}-0.011 \\
(-2.95)\end{array}$ & $\begin{array}{l}0.008 \\
(3.13) \\
\end{array}$ & $\begin{array}{l}-0.001 \\
(-0.53)\end{array}$ & $\begin{array}{l}0.002 \\
(1.06) \\
\end{array}$ & $\begin{array}{l}0.014 \\
(5.24) \\
\end{array}$ \\
\hline R-sq. & 0.063 & 0.095 & 0.057 & 0.103 & 0.032 & 0.128 & 0.186 & 0.255 & 0.227 & 0.163 & 0.109 & 0.140 & 0.035 & 0.136 & 0.213 \\
\hline
\end{tabular}

Notes: Series names in the first row are the same as for Table 1. Explanatory variables in the first column are the change in the 3-month Treasury bill (3m-

TB), the 10-year Treasury bond-3-month Treasury bill term structure (TS), the change in the S\&P500 dividend-price ratio (DP), the change in the monthly consumer price index (Infl), the change in monthly industrial production (IP), the purchasing managers index (PMI), the consumer sentiment index (CS) and the return (R) on each asset. The constant term is represented by the Cnst. The entries are the coefficients with Newey-West $t$-statistics in parentheses, with the R-squared value in the final row for the regression given by equations (1)-(2). 
Table 4. Bai-Perron Break Dates

\begin{tabular}{|l|l|l|l|l|l|}
\hline & Break 1 & Break 2 & Break 3 & Break 4 & Break 5 \\
\hline SP-BD & $1987: 05$ & $1992: 12$ & $1998: 07$ & $2007: 11$ & - \\
\hline SP-BAA & $1985: 11$ & $1991: 09$ & $1997: 04$ & $2005: 12$ & $2011: 07$ \\
\hline SP-WRD & $1992: 01$ & $1997: 08$ & $2003: 04$ & $2011: 10$ & - \\
\hline SP-COM & $1987: 10$ & $1993: 05$ & $2002: 09$ & $2008: 10$ & - \\
\hline SP-GD & $1990: 11$ & $1999: 05$ & $2005: 08$ & $2011: 12$ & - \\
\hline SP-REIT & $1985: 08$ & $1991: 09$ & $2000: 07$ & $2006: 02$ & $2011: 12$ \\
\hline SP-DOL & $1985: 09$ & $1991: 12$ & $1998: 09$ & $2004: 04$ & $2009: 11$ \\
\hline BD-BAA & $1989: 07$ & $1997: 04$ & $2002: 11$ & $2008: 11$ & - \\
\hline BD-WRD & $1995: 03$ & $2000: 10$ & $2008: 03$ & - & - \\
\hline BD-COM & $1985: 08$ & $1993: 01$ & $1998: 10$ & $2004: 05$ & $2010: 04$ \\
\hline BD-GD & $1990: 08$ & $1996: 03$ & $2004: 02$ & $2011: 12$ & - \\
\hline BD-REIT & $1986: 03$ & $1996: 12$ & $2004: 04$ & $2011: 09$ & - \\
\hline BD-DOL & $1992: 12$ & $1998: 07$ & $2004: 12$ & $2010: 07$ & - \\
\hline BAA-WRD & $1990: 06$ & $1998: 06$ & $2004: 01$ & $2010: 08$ & - \\
\hline BAA-COM & $1991: 09$ & $1999: 11$ & $2008: 09$ & - & - \\
\hline BAA-GD & $1985: 08$ & $1992: 02$ & $1997: 10$ & $2003: 08$ & $2011: 12$ \\
\hline BAA-REIT & $1989: 10$ & $1996: 10$ & $2002: 10$ & $2011: 06$ & - \\
\hline BAA-DOL & $1988: 01$ & $1999: 12$ & $2010: 07$ & - & - \\
\hline WRD-COM & $1990: 08$ & $1997: 06$ & $2005: 11$ & $2011: 11$ & - \\
\hline WRD-GD & $1988: 01$ & $1994: 09$ & $2002: 07$ & $2008: 11$ & - \\
\hline WRD-REIT & $1988: 10$ & $1999: 08$ & $2005: 03$ & $2011: 12$ & - \\
\hline WRD-DOL & $1990: 09$ & $1999: 01$ & $2004: 08$ & $2010: 10$ & - \\
\hline COM-GD & $1985: 11$ & $1991: 10$ & $1997: 11$ & $2006: 05$ & $2011: 12$ \\
\hline COM-REIT & $1985: 08$ & $1993: 04$ & $2000: 04$ & $2009: 11$ & - \\
\hline COM-DOL & $1987: 05$ & $1992: 12$ & $1998: 07$ & $2005: 12$ & $2011: 09$ \\
\hline GD-REIT & $1985: 11$ & $1994: 10$ & $2004: 03$ & $2009: 10$ & - \\
\hline GD-DOL & $1990: 10$ & $1997: 01$ & $2004: 04$ & $2010: 07$ & - \\
\hline REIT-DOL & $1985: 11$ & $1991: 07$ & $1997: 02$ & $2004: 04$ & $2011: 07$ \\
\hline $\begin{array}{l}\text { Notes: Series } \\
\text { statistically significant in the Bai-Perron breakpoint tests. }\end{array}$ & \\
\hline
\end{tabular}


Table 5(I). Time-Varying Correlation Markov Switching Regression Results

\begin{tabular}{|c|c|c|c|c|c|c|c|c|c|c|c|c|c|c|c|}
\hline & SP-BD & $\begin{array}{l}\text { SP- } \\
\text { BAA }\end{array}$ & $\begin{array}{l}\text { SP- } \\
\text { WRD }\end{array}$ & $\begin{array}{l}\mathrm{SP}- \\
\mathrm{COM}\end{array}$ & SP-GD & $\begin{array}{l}\text { SP- } \\
\text { REIT }\end{array}$ & $\begin{array}{l}\text { SP- } \\
\text { DOL }\end{array}$ & $\begin{array}{l}\text { BD- } \\
\text { BAA }\end{array}$ & $\begin{array}{l}\text { BD- } \\
\text { WRD }\end{array}$ & $\begin{array}{l}\text { BD- } \\
\text { COM }\end{array}$ & $\begin{array}{l}\text { BD- } \\
\text { GD } \\
\end{array}$ & $\begin{array}{l}\text { BD- } \\
\text { REIT }\end{array}$ & $\begin{array}{l}\text { BD- } \\
\text { DOL }\end{array}$ & & \\
\hline & \multicolumn{15}{|c|}{ Regime 1} \\
\hline Cnst & $\begin{array}{l}0.055 \\
(0.32)\end{array}$ & $\begin{array}{l}0.682 \\
(5.30)\end{array}$ & $\begin{array}{l}0.576 \\
(3.02)\end{array}$ & $\begin{array}{l}1.466 \\
(10.16)\end{array}$ & $\begin{array}{l}0.789 \\
(5.50)\end{array}$ & $\begin{array}{l}1.096 \\
(13.36)\end{array}$ & $\begin{array}{l}-0.720 \\
(-2.91)\end{array}$ & $\begin{array}{l}-0.533 \\
(-4.31)\end{array}$ & $\begin{array}{l}0.394 \\
(2.03)\end{array}$ & $\begin{array}{l}-0.058 \\
(-0.36)\end{array}$ & $\begin{array}{l}-0.093 \\
(-0.69)\end{array}$ & $\begin{array}{l}0.391 \\
(2.32)\end{array}$ & $\begin{array}{l}-0.692 \\
(-3.72)\end{array}$ & & \\
\hline $3 \mathrm{~m}-\mathrm{TB}$ & $\begin{array}{l}0.005 \\
(0.14) \\
\end{array}$ & $\begin{array}{l}0.029 \\
(0.95) \\
\end{array}$ & $\begin{array}{l}-0.52 \\
(-1.30) \\
\end{array}$ & $\begin{array}{l}0.020 \\
(0.72) \\
\end{array}$ & $\begin{array}{l}-0.007 \\
(-0.24)\end{array}$ & $\begin{array}{l}0.017 \\
(0.97) \\
\end{array}$ & $\begin{array}{l}0.035 \\
(0.86) \\
\end{array}$ & $\begin{array}{l}-0.045 \\
(-2.05)\end{array}$ & $\begin{array}{l}-0.037 \\
(-1.08)\end{array}$ & $\begin{array}{l}-0.013 \\
(-0.50)\end{array}$ & $\begin{array}{l}-0.021 \\
-(0.77)\end{array}$ & $\begin{array}{l}0.012 \\
(0.35)\end{array}$ & $\begin{array}{l}-0.048 \\
(-0.89)\end{array}$ & & \\
\hline $\mathrm{TS}$ & $\begin{array}{l}0.039 \\
(2.75) \\
\end{array}$ & $\begin{array}{l}-0.029 \\
(-2.76)\end{array}$ & $\begin{array}{l}-0.036 \\
(-2.26)\end{array}$ & $\begin{array}{l}0.004 \\
(0.38) \\
\end{array}$ & $\begin{array}{l}-0.026 \\
(-1.92)\end{array}$ & $\begin{array}{l}0.027 \\
(3.80)\end{array}$ & $\begin{array}{l}0.055 \\
(4.35)\end{array}$ & $\begin{array}{l}0.008 \\
(0.84) \\
\end{array}$ & $\begin{array}{l}0.048 \\
(3.44)\end{array}$ & $\begin{array}{l}0.030 \\
(2.24)\end{array}$ & $\begin{array}{l}0.006 \\
(0.48) \\
\end{array}$ & $\begin{array}{l}0.048 \\
(2.75) \\
\end{array}$ & $\begin{array}{l}-0.057 \\
(-3.82)\end{array}$ & & \\
\hline DP & $\begin{array}{l}1.824 \\
(1.42)\end{array}$ & $\begin{array}{l}-0.082 \\
(-0.10)\end{array}$ & $\begin{array}{l}2.379 \\
(1.49)\end{array}$ & $\begin{array}{l}0.843 \\
(1.12)\end{array}$ & $\begin{array}{l}0.984 \\
(1.06)\end{array}$ & $\begin{array}{l}0.512 \\
(1.04)\end{array}$ & $\begin{array}{l}-0.849 \\
(-0.64)\end{array}$ & $\begin{array}{l}2.383 \\
(2.30)\end{array}$ & $\begin{array}{l}-0.920 \\
(-0.81)\end{array}$ & $\begin{array}{l}-2.968 \\
(-2.09)\end{array}$ & $\begin{array}{l}0.079 \\
(0.09)\end{array}$ & $\begin{array}{l}-0.629 \\
(-0.58)\end{array}$ & $\begin{array}{l}2.024 \\
(-2.14)\end{array}$ & & \\
\hline Infl & $\begin{array}{l}7.463 \\
(1.48) \\
\end{array}$ & $\begin{array}{l}1.102 \\
(0.34)\end{array}$ & $\begin{array}{l}-18.40 \\
(-3.26)\end{array}$ & $\begin{array}{l}1.195 \\
(0.35)\end{array}$ & $\begin{array}{l}5.943 \\
(1.52)\end{array}$ & $\begin{array}{l}2.738 \\
(1.35)\end{array}$ & $\begin{array}{l}6.196 \\
(-1.11)\end{array}$ & $\begin{array}{l}-1.283 \\
(-0.38)\end{array}$ & $\begin{array}{l}4.192 \\
(0.65)\end{array}$ & $\begin{array}{l}-1.166 \\
(-0.24)\end{array}$ & $\begin{array}{l}-9.721 \\
(-2.67)\end{array}$ & $\begin{array}{l}-4.814 \\
(-1.01)\end{array}$ & $\begin{array}{l}-8.904 \\
(-2.00)\end{array}$ & & \\
\hline IP & $\begin{array}{l}2.785 \\
(1.05)\end{array}$ & $\begin{array}{l}-1.330 \\
(-0.76)\end{array}$ & $\begin{array}{l}-0.552 \\
(-0.18)\end{array}$ & $\begin{array}{l}0.548 \\
(0.28)\end{array}$ & $\begin{array}{l}2.945 \\
(1.32)\end{array}$ & $\begin{array}{l}1.415 \\
(1.23)\end{array}$ & $\begin{array}{l}-2.420 \\
(-0.94)\end{array}$ & $\begin{array}{l}0.663 \\
(0.38) \\
\end{array}$ & $\begin{array}{l}1.963 \\
(0.68)\end{array}$ & $\begin{array}{l}1.076 \\
(0.43) \\
\end{array}$ & $\begin{array}{l}-5.074 \\
(-2.57)\end{array}$ & $\begin{array}{l}-1.863 \\
(-0.68)\end{array}$ & $\begin{array}{l}-2.928 \\
(-1.18)\end{array}$ & & \\
\hline PMI & $\begin{array}{l}-0.004 \\
(-1.13)\end{array}$ & $\begin{array}{l}-0.002 \\
(-0.98)\end{array}$ & $\begin{array}{l}0.003 \\
(0.69)\end{array}$ & $\begin{array}{l}0.007 \\
(2.61)\end{array}$ & $\begin{array}{l}-0.004 \\
(-1.42)\end{array}$ & $\begin{array}{l}-0.001 \\
(-0.07)\end{array}$ & $\begin{array}{l}-0.011 \\
(-2.39)\end{array}$ & $\begin{array}{l}0.017 \\
(6.67)\end{array}$ & $\begin{array}{l}-0.008 \\
(-1.93)\end{array}$ & $\begin{array}{l}-0.006 \\
(-1.63)\end{array}$ & $\begin{array}{l}0.011 \\
(4.16)\end{array}$ & $\begin{array}{l}0.004 \\
(0.84)\end{array}$ & $\begin{array}{l}0.014 \\
(3.92)\end{array}$ & & \\
\hline $\mathrm{CS}$ & $\begin{array}{l}0.005 \\
(3.18) \\
\end{array}$ & $\begin{array}{l}-0.003 \\
(-2.50)\end{array}$ & $\begin{array}{l}-0.002 \\
(-0.84)\end{array}$ & $\begin{array}{l}-0.017 \\
(-16.8)\end{array}$ & $\begin{array}{l}-0.003 \\
(-2.63)\end{array}$ & $\begin{array}{l}-0.005 \\
(-7.72)\end{array}$ & $\begin{array}{l}0.015 \\
(8.08) \\
\end{array}$ & $\begin{array}{l}-0.002 \\
(-1.67)\end{array}$ & $\begin{array}{l}0.002 \\
(1.11)\end{array}$ & $\begin{array}{l}0.006 \\
(3.91)\end{array}$ & $\begin{array}{l}-0.002 \\
(-2.41)\end{array}$ & $\begin{array}{l}-0.002 \\
(-0.89)\end{array}$ & $\begin{array}{l}0.002 \\
(1.30)\end{array}$ & & \\
\hline \multirow[t]{2}{*}{ Var } & $\begin{array}{l}0.237 \\
(29.86)\end{array}$ & $\begin{array}{l}0.157 \\
(36.01)\end{array}$ & $\begin{array}{l}0.205 \\
(31.32)\end{array}$ & $\begin{array}{l}0.152 \\
(31.03)\end{array}$ & $\begin{array}{l}0.195 \\
(29.76)\end{array}$ & $\begin{array}{l}0.108 \\
(45.89)\end{array}$ & $\begin{array}{l}0.185 \\
(28.56)\end{array}$ & $\begin{array}{l}0.135 \\
(35.05)\end{array}$ & $\begin{array}{l}0.239 \\
(32.10)\end{array}$ & $\begin{array}{l}0.166 \\
(29.22)\end{array}$ & $\begin{array}{l}0.192 \\
(38.27)\end{array}$ & $\begin{array}{l}0.171 \\
(25.08)\end{array}$ & $\begin{array}{l}0.229 \\
(34.20)\end{array}$ & & \\
\hline & \multicolumn{15}{|c|}{ Regime 2} \\
\hline Cnst & $\begin{array}{l}-2.780 \\
(-12.6)\end{array}$ & $\begin{array}{l}0.425 \\
(2.88)\end{array}$ & $\begin{array}{l}1.118 \\
(20.67)\end{array}$ & $\begin{array}{l}-0.167 \\
(-0.84)\end{array}$ & $\begin{array}{l}-0.631 \\
(-3.32)\end{array}$ & $\begin{array}{l}0.925 \\
(5.04)\end{array}$ & $\begin{array}{l}-1.143 \\
(-5.19)\end{array}$ & $\begin{array}{l}-1.351 \\
(-8.66)\end{array}$ & $\begin{array}{l}-0.708 \\
(-2.93)\end{array}$ & $\begin{array}{l}-0.116 \\
(-0.73)\end{array}$ & $\begin{array}{l}0.387 \\
(2.11)\end{array}$ & $\begin{array}{l}0.189 \\
(0.87)\end{array}$ & $\begin{array}{l}-0.552 \\
(-4.27)\end{array}$ & & \\
\hline $3 \mathrm{~m}-\mathrm{TB}$ & $\begin{array}{l}0.018 \\
(0.27) \\
\end{array}$ & $\begin{array}{l}-0.023 \\
(-0.77)\end{array}$ & $\begin{array}{l}0.002 \\
(0.13) \\
\end{array}$ & $\begin{array}{l}0.021 \\
(0.43) \\
\end{array}$ & $\begin{array}{l}-0.030 \\
(-0.56)\end{array}$ & $\begin{array}{l}0.052 \\
(1.22)\end{array}$ & $\begin{array}{l}0.028 \\
(0.91) \\
\end{array}$ & $\begin{array}{l}0.027 \\
(0.59) \\
\end{array}$ & $\begin{array}{l}-0.019 \\
(-0.30)\end{array}$ & $\begin{array}{l}0.005 \\
(0.09) \\
\end{array}$ & $\begin{array}{l}0.024 \\
(0.41) \\
\end{array}$ & $\begin{array}{l}-0.021 \\
(-0.47)\end{array}$ & $\begin{array}{l}0.019 \\
(0.74)\end{array}$ & & \\
\hline $\mathrm{TS}$ & $\begin{array}{l}-0.069 \\
(-4.36)\end{array}$ & $\begin{array}{l}-0.028 \\
(-2.10)\end{array}$ & $\begin{array}{l}0.001 \\
(0.05)\end{array}$ & $\begin{array}{l}-0.007 \\
(-0.45)\end{array}$ & $\begin{array}{l}-0.012 \\
(-0.75)\end{array}$ & $\begin{array}{l}0.031 \\
(2.20) \\
\end{array}$ & $\begin{array}{l}0.093 \\
(6.10) \\
\end{array}$ & $\begin{array}{l}0.025 \\
(2.01) \\
\end{array}$ & $\begin{array}{l}-0.009 \\
(-0.47)\end{array}$ & $\begin{array}{l}-0.014 \\
(-0.79)\end{array}$ & $\begin{array}{l}-0.018 \\
(-1.23)\end{array}$ & $\begin{array}{l}-0.038 \\
(-2.87)\end{array}$ & $\begin{array}{l}-0.031 \\
(-2.73)\end{array}$ & & \\
\hline DP & $\begin{array}{l}-0.645 \\
(-0.70)\end{array}$ & $\begin{array}{l}0.662 \\
(0.79)\end{array}$ & $\begin{array}{l}0.178 \\
(0.65)\end{array}$ & $\begin{array}{l}-0.621 \\
(-0.46)\end{array}$ & $\begin{array}{l}0.607 \\
(0.63)\end{array}$ & $\begin{array}{l}0.835 \\
(0.85)\end{array}$ & $\begin{array}{l}1.057 \\
(1.48) \\
\end{array}$ & $\begin{array}{l}0.655 \\
(0.96) \\
\end{array}$ & $\begin{array}{l}-0.722 \\
(-0.75)\end{array}$ & $\begin{array}{l}-0.952 \\
(-1.28)\end{array}$ & $\begin{array}{l}-1.178 \\
(-1.17) \\
\end{array}$ & $\begin{array}{l}-1.204 \\
(-1.16)\end{array}$ & $\begin{array}{l}0.606 \\
(0.52)\end{array}$ & & \\
\hline Infl & $\begin{array}{l}1.736 \\
(0.40)\end{array}$ & $\begin{array}{l}7.540 \\
(1.82)\end{array}$ & $\begin{array}{l}-3.602 \\
(-2.61)\end{array}$ & $\begin{array}{l}1.415 \\
(0.26)\end{array}$ & $\begin{array}{l}-6.674 \\
(-1.39)\end{array}$ & $\begin{array}{l}-2.216 \\
(-0.47)\end{array}$ & $\begin{array}{l}4.085 \\
(1.12)\end{array}$ & $\begin{array}{l}0.584 \\
(0.16)\end{array}$ & $\begin{array}{l}-4.144 \\
(-0.92)\end{array}$ & $\begin{array}{l}-3.918 \\
(0.93)\end{array}$ & $\begin{array}{l}4.942 \\
(1.01)\end{array}$ & $\begin{array}{l}2.099 \\
(0.46)\end{array}$ & $\begin{array}{l}-3.368 \\
(-0.71)\end{array}$ & & \\
\hline
\end{tabular}




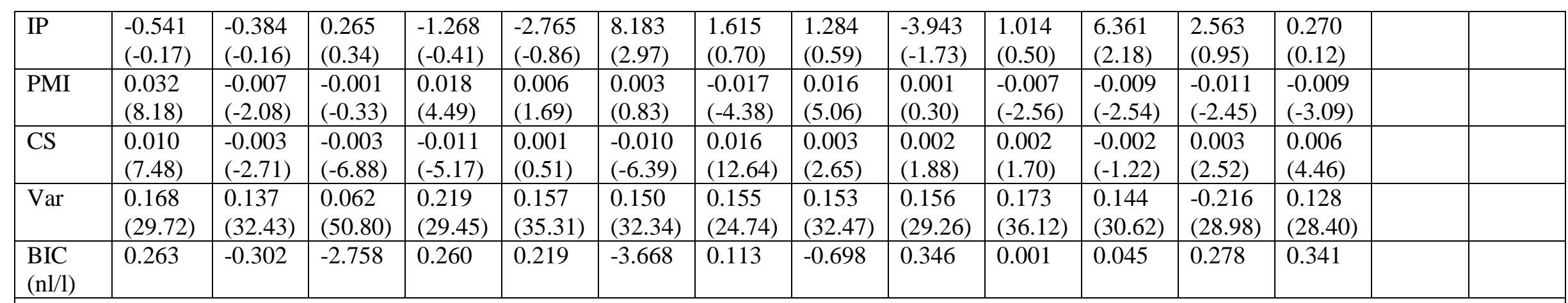

Notes: Series names in the first row are the same as for Table 1. Explanatory variables in the first column are the same as in Table 3. The entries are the coefficients with Newey-West $t$-statistics in parentheses for the Markov switching regression given by equations (3)-(4). The final row contains the BIC value from the non-linear (nl, Markov-switching model) dividend by the BIC value from the linear model (1, Table 3 ); thus, any value less than one indicates a preference for the non-linear model. 
Table 5(II). Time-Varying Correlation Markov Switching Regression Results

\begin{tabular}{|c|c|c|c|c|c|c|c|c|c|c|c|c|c|c|c|}
\hline & $\begin{array}{l}\text { AA- } \\
\text { RD }\end{array}$ & $\begin{array}{l}\mathrm{AA}- \\
\mathrm{OM}\end{array}$ & $\begin{array}{l}\text { BAA- } \\
\text { GD }\end{array}$ & $\begin{array}{l}\text { AA- } \\
\text { EIT }\end{array}$ & $\begin{array}{l}\text { BAA- } \\
\text { DOL }\end{array}$ & $\begin{array}{l}\text { WRD- } \\
\text { COM }\end{array}$ & $\begin{array}{l}\text { WRD- } \\
\text { GD }\end{array}$ & \begin{tabular}{|l} 
WRD- \\
REIT
\end{tabular} & $\begin{array}{l}\text { WRD- } \\
\text { DOL }\end{array}$ & $\begin{array}{l}\text { COM- } \\
\text { GD }\end{array}$ & $\begin{array}{l}\text { COM- } \\
\text { REIT }\end{array}$ & $\begin{array}{l}\text { COM- } \\
\text { DOL }\end{array}$ & \begin{tabular}{|l} 
GD- \\
REIT
\end{tabular} & $\begin{array}{l}\text { GD- } \\
\text { DOL }\end{array}$ & $\begin{array}{l}\text { REIT- } \\
\text { DOL }\end{array}$ \\
\hline & \multicolumn{15}{|c|}{ Regime 1} \\
\hline Cnst & $\begin{array}{l}61 \\
27)\end{array}$ & $\begin{array}{l}802 \\
4.66)\end{array}$ & $\begin{array}{l}310 \\
.00)\end{array}$ & $\begin{array}{l}80 \\
06)\end{array}$ & $\begin{array}{l}0.228 \\
(1.21)\end{array}$ & $\begin{array}{l}82 \\
72)\end{array}$ & $\begin{array}{l}736 \\
.54)\end{array}$ & $\begin{array}{l}1.174 \\
(10.74)\end{array}$ & & $\begin{array}{l}1.623 \\
(11.55)\end{array}$ & $\begin{array}{l}226 \\
3.96)\end{array}$ & & $\begin{array}{l}78 \\
7)\end{array}$ & $\begin{array}{l}0 \\
6)\end{array}$ & $\begin{array}{l}018 \\
.09)\end{array}$ \\
\hline $3 m-T$ & & $\begin{array}{l}021 \\
.55)\end{array}$ & $\begin{array}{l}-0.025 \\
(-0.96)\end{array}$ & $\begin{array}{l}0.025 \\
(0.95)\end{array}$ & & $\begin{array}{l}-0.006 \\
(-0.21)\end{array}$ & $\begin{array}{l}0.010 \\
(0.41)\end{array}$ & & & $\begin{array}{l}0.046 \\
(1.84)\end{array}$ & $\begin{array}{l}0.012 \\
(0.48)\end{array}$ & & & $\begin{array}{l}0.106 \\
-1.15)\end{array}$ & $\begin{array}{l}0.017 \\
(0.37)\end{array}$ \\
\hline $\mathrm{TS}$ & & $\begin{array}{l}-0.022 \\
(-1.32)\end{array}$ & & $\begin{array}{l}0.027 \\
(2.48)\end{array}$ & & & & & & & $\begin{array}{l}-0.017 \\
(-1.45)\end{array}$ & & & & \\
\hline DP & & $\begin{array}{l}1.513 \\
(1.29)\end{array}$ & & & & & & & & & $\begin{array}{l}1.043 \\
(1.37)\end{array}$ & & & & $\begin{array}{l}-0.214 \\
(-0.15)\end{array}$ \\
\hline In & & & & & & & & & & & $\begin{array}{l}8.040 \\
(2.42)\end{array}$ & & & & \\
\hline IP & & & & & & & & & & $\begin{array}{l}4.044 \\
(1.62)\end{array}$ & $\begin{array}{l}2.104 \\
(1.16)\end{array}$ & & & $\begin{array}{l}-1.376 \\
(-0.38)\end{array}$ & \\
\hline $\mathrm{P}$ & & & & & & & & & & $\begin{array}{l}-0.011 \\
(-4.07)\end{array}$ & $\begin{array}{l}0.003 \\
(0.95)\end{array}$ & & & & \\
\hline $\mathrm{CS}$ & $\begin{array}{l}002 \\
.29)\end{array}$ & $\begin{array}{l}-0.003 \\
(-1.84)\end{array}$ & -0.001 & $\begin{array}{l}-0.001 \\
(-0.99)\end{array}$ & $\begin{array}{l}-0.002 \\
(-1.17)\end{array}$ & & $\begin{array}{l}0.001 \\
(0.43)\end{array}$ & & & $\begin{array}{l}-0.006 \\
(-6.50)\end{array}$ & $\begin{array}{l}-0.010 \\
(-11.5)\end{array}$ & & & $\begin{array}{l}.006 \\
2.65)\end{array}$ & \\
\hline \multirow[t]{2}{*}{ Var } & $\begin{array}{l}50 \\
85) \\
\end{array}$ & $\begin{array}{l}0.194 \\
(31.65) \\
\end{array}$ & $\begin{array}{l}0.148 \\
(35.68) \\
\end{array}$ & $\begin{array}{l}0.159 \\
(32.78)\end{array}$ & $\begin{array}{l}0.183 \\
(30.61) \\
\end{array}$ & $\begin{array}{l}0.163 \\
(30.39) \\
\end{array}$ & $\begin{array}{l}0.141 \\
(30.78)\end{array}$ & $\begin{array}{l}0.144 \\
(28.03)\end{array}$ & & $\begin{array}{l}0.142 \\
(32.23) \\
\end{array}$ & $\begin{array}{l}0.130 \\
(30.98)\end{array}$ & & $\begin{array}{l}.221 \\
32.04) \\
\end{array}$ & $\begin{array}{l}0.176 \\
(25.13) \\
\end{array}$ & $\begin{array}{l}0.223 \\
(31.19) \\
\end{array}$ \\
\hline & \multicolumn{15}{|c|}{ Regime 2} \\
\hline Cnst & $\begin{array}{l}786 \\
29)\end{array}$ & $\begin{array}{l}57 \\
60) \\
\end{array}$ & $\overline{595}$ & $\begin{array}{l}347 \\
.30)\end{array}$ & -0.083 & $\begin{array}{l}114 \\
.96)\end{array}$ & $\begin{array}{l}-0.471 \\
-236\end{array}$ & & & $\begin{array}{l}1.141 \\
(6.28)\end{array}$ & $\begin{array}{l}816 \\
.58)\end{array}$ & $\begin{array}{l}61 \\
73)\end{array}$ & $\begin{array}{l}12 \\
85)\end{array}$ & $\begin{array}{l}.812 \\
7.28)\end{array}$ & 863 \\
\hline $3 \mathrm{~m}-\mathrm{T}$ & & & & & & & & & & & & & & $\begin{array}{l}-0.021 \\
(-0.96)\end{array}$ & \\
\hline $\mathrm{TS}$ & $\begin{array}{l}-0.022 \\
(-1.10)\end{array}$ & $\begin{array}{l}-0.065 \\
(-4.83)\end{array}$ & $\begin{array}{l}0.015 \\
(1.14)\end{array}$ & $\begin{array}{l}0.063 \\
(2.37)\end{array}$ & & $\begin{array}{l}-0.041 \\
(-2.07)\end{array}$ & $\begin{array}{l}-0.135 \\
(-6.85)\end{array}$ & & & $\begin{array}{l}-0.042 \\
(-2.14)\end{array}$ & $\begin{array}{l}-0.032 \\
(-2.25)\end{array}$ & & $\begin{array}{l}-0.039 \\
(-2.70)\end{array}$ & $\begin{array}{l}0.016 \\
(1.83)\end{array}$ & $\begin{array}{l}-0.022 \\
(-1.74)\end{array}$ \\
\hline DP & $\begin{array}{l}-0.500 \\
(-0.52)\end{array}$ & $\begin{array}{l}-0.073 \\
(-0.08)\end{array}$ & $\begin{array}{l}-0.181 \\
(-0.16)\end{array}$ & $\begin{array}{l}-1.369 \\
(-1.67)\end{array}$ & $\begin{array}{l}0.905 \\
(1.16)\end{array}$ & $\begin{array}{l}0.513 \\
(0.42)\end{array}$ & $\begin{array}{l}1.329 \\
(1.21)\end{array}$ & & $\begin{array}{l}-0.538 \\
(-2.10)\end{array}$ & $\begin{array}{l}-0.940 \\
(-0.82)\end{array}$ & $\begin{array}{l}0.184 \\
(0.17)\end{array}$ & $\begin{array}{l}-1.480 \\
(-1.99)\end{array}$ & $\begin{array}{l}0.466 \\
(0.45)\end{array}$ & $\begin{array}{l}-0.900 \\
(-1.33)\end{array}$ & $\begin{array}{l}-0.317 \\
(-0.45)\end{array}$ \\
\hline Infl & $\begin{array}{l}3.918 \\
(0.74)\end{array}$ & $\begin{array}{l}-5.684 \\
(-1.46)\end{array}$ & $\begin{array}{l}-20.38 \\
(-4.38)\end{array}$ & $\begin{array}{l}6.589 \\
(1.38)\end{array}$ & $\begin{array}{l}-13.42 \\
(-3.86)\end{array}$ & $\begin{array}{l}9.516 \\
(1.54)\end{array}$ & $\begin{array}{l}8.964 \\
(1.65)\end{array}$ & $\begin{array}{l}-5.639 \\
(-1.26)\end{array}$ & $\begin{array}{l}-2.210 \\
(-1.68)\end{array}$ & $\begin{array}{l}1.818 \\
(0.37)\end{array}$ & $\begin{array}{l}4.430 \\
(0.94)\end{array}$ & $\begin{array}{l}6.854 \\
(2.10)\end{array}$ & $\begin{array}{l}-12.99 \\
(-2.78)\end{array}$ & $\begin{array}{l}2.920 \\
(1.04)\end{array}$ & $\begin{array}{l}0.806 \\
(0.23)\end{array}$ \\
\hline
\end{tabular}




\begin{tabular}{|c|c|c|c|c|c|c|c|c|c|c|c|c|c|c|c|}
\hline IP & $\begin{array}{l}0.990 \\
(0.32) \\
\end{array}$ & $\begin{array}{l}-2.232 \\
(-0.92)\end{array}$ & $\begin{array}{l}1.107 \\
(0.43) \\
\end{array}$ & $\begin{array}{l}3.096 \\
(1.06) \\
\end{array}$ & $\begin{array}{l}2.659 \\
(1.45) \\
\end{array}$ & $\begin{array}{l}-2.641 \\
(-0.85)\end{array}$ & $\begin{array}{l}1.869 \\
(0.69) \\
\end{array}$ & $\begin{array}{l}3.056 \\
(1.10) \\
\end{array}$ & $\begin{array}{l}-1.635 \\
(-1.95)\end{array}$ & $\begin{array}{l}-2.577 \\
(-1.17)\end{array}$ & $\begin{array}{l}3.728 \\
(1.31) \\
\end{array}$ & $\begin{array}{l}-0.344 \\
(-0.18)\end{array}$ & $\begin{array}{l}-0.394 \\
(-0.17)\end{array}$ & $\begin{array}{l}2.969 \\
(1.77) \\
\end{array}$ & $\begin{array}{l}3.280 \\
(1.53)\end{array}$ \\
\hline PMI & $\begin{array}{l}0.017 \\
(3.97) \\
\end{array}$ & $\begin{array}{l}0.001 \\
(0.22) \\
\end{array}$ & $\begin{array}{l}0.007 \\
(2.23) \\
\end{array}$ & $\begin{array}{l}-0.006 \\
(-1.11) \\
\end{array}$ & $\begin{array}{l}0.005 \\
(1.81) \\
\end{array}$ & $\begin{array}{l}0.028 \\
(6.98) \\
\end{array}$ & $\begin{array}{l}0.011 \\
(2.91) \\
\end{array}$ & $\begin{array}{l}0.010 \\
(2.52) \\
\end{array}$ & $\begin{array}{l}0.001 \\
(0.71) \\
\end{array}$ & $\begin{array}{l}-0.003 \\
(-0.94)\end{array}$ & $\begin{array}{l}0.025 \\
(6.89) \\
\end{array}$ & $\begin{array}{l}-0.008 \\
(-2.80) \\
\end{array}$ & $\begin{array}{l}0.011 \\
(3.65) \\
\end{array}$ & $\begin{array}{l}-0.002 \\
(-0.75)\end{array}$ & $\begin{array}{l}-0.013 \\
(-4.09)\end{array}$ \\
\hline CS & $\begin{array}{l}-0.002 \\
(-1013)\end{array}$ & $\begin{array}{l}-0.005 \\
(-3.57)\end{array}$ & $\begin{array}{l}0.001 \\
(0.49) \\
\end{array}$ & $\begin{array}{l}0.004 \\
(3.10) \\
\end{array}$ & $\begin{array}{l}-0.006 \\
(-4.81)\end{array}$ & $\begin{array}{l}-0.004 \\
(-1.98)\end{array}$ & $\begin{array}{l}0.002 \\
(0.86) \\
\end{array}$ & $\begin{array}{l}-0.014 \\
(-10.6)\end{array}$ & $\begin{array}{l}0.003 \\
(6.93) \\
\end{array}$ & $\begin{array}{l}-0.011 \\
(-6.42)\end{array}$ & $\begin{array}{l}-0.007 \\
(-4.51)\end{array}$ & $\begin{array}{l}0.008 \\
(7.43) \\
\end{array}$ & $\begin{array}{l}-0.004 \\
(-2.87)\end{array}$ & $\begin{array}{l}0.004 \\
(4.64) \\
\end{array}$ & $\begin{array}{l}0.013 \\
(10.36)\end{array}$ \\
\hline Var & $\begin{array}{l}0.198 \\
(30.61)\end{array}$ & $\begin{array}{l}0.179 \\
(31.89) \\
\end{array}$ & $\begin{array}{l}0.167 \\
(29.47) \\
\end{array}$ & $\begin{array}{l}0.176 \\
(22.92)\end{array}$ & $\begin{array}{l}0.141 \\
(30.69)\end{array}$ & $\begin{array}{l}0.198 \\
(29.10)\end{array}$ & $\begin{array}{l}0.191 \\
(33.09)\end{array}$ & $\begin{array}{l}0.151 \\
(35.92)\end{array}$ & $\begin{array}{l}0.056 \\
(41.24)\end{array}$ & $\begin{array}{l}0.197 \\
(30.86)\end{array}$ & $\begin{array}{l}0.225 \\
(33.11)\end{array}$ & $\begin{array}{l}0.155 \\
(33.42)\end{array}$ & $\begin{array}{l}0.130 \\
(28.10)\end{array}$ & $\begin{array}{l}0.162 \\
(42.52)\end{array}$ & $\begin{array}{l}0.149 \\
(28.67)\end{array}$ \\
\hline $\begin{array}{l}\text { BIC } \\
\text { (n1/l) }\end{array}$ & 0.241 & 0.253 & -0.219 & 0.059 & -0.031 & 0.137 & 0.211 & -0.211 & -2.241 & 0.072 & 0.176 & 0.058 & 0.271 & -0.065 & 0.297 \\
\hline
\end{tabular}

Notes: Series names in the first row are the same as for Table 1. Explanatory variables in the first column are the same as in Table 3. The entries are the coefficients with Newey-West $t$-statistics in parentheses for the Markov switching regression given by equations (3)-(4). The final row contains the BIC value from the non-linear (nl, Markov-switching model) dividend by the BIC value from the linear model (1, Table 3 ); thus, any value less than one indicates a preference for the non-linear model. 
Table 6. Sharpe Ratios

\begin{tabular}{|c|c|c|c|}
\hline \multicolumn{4}{|c|}{ Sharpe Ratio for Safe and Risky Portfolios According to the Sign of the Time-Varying Correlation } \\
\hline & Correlation $(-1)>0$ & Correlation $(-1)<0$ & \\
\hline Risky & 0.102 & 0.008 & \\
\hline Safe & -0.039 & 0.069 & \\
\hline \multicolumn{4}{|c|}{ Sharpe Ratios for Portfolios } \\
\hline Safe & Risky & $60 / 40$ & Trade \\
\hline 0.014 & 0.063 & 0.071 & 0.102 \\
\hline \multicolumn{4}{|c|}{ Expected Return Regressions } \\
\hline Alpha & MKT & SMB & HML \\
\hline \multicolumn{4}{|c|}{ 60/40 Portfolio } \\
\hline $\begin{array}{l}0.008 \\
(1.74)\end{array}$ & $\begin{array}{c}0.546 \\
(21.44)\end{array}$ & - & - \\
\hline $\begin{array}{l}0.002 \\
(1.02)\end{array}$ & $\begin{array}{c}0.559 \\
(21.64)\end{array}$ & $\begin{array}{l}-0.060 \\
(-2.09)\end{array}$ & $\begin{array}{c}0.042 \\
(1.23)\end{array}$ \\
\hline \multicolumn{4}{|c|}{ Switching Portfolio } \\
\hline $\begin{array}{l}0.056 \\
(3.31)\end{array}$ & $\begin{array}{l}0.681 \\
(6.42)\end{array}$ & - & - \\
\hline $\begin{array}{l}0.031 \\
(2.66) \\
\end{array}$ & $\begin{array}{l}0.691 \\
(6.54) \\
\end{array}$ & $\begin{array}{l}0.151 \\
(2.88) \\
\end{array}$ & $\begin{array}{c}0.141 \\
(1.84)\end{array}$ \\
\hline $\begin{array}{l}\text { Notes: The discussio } \\
\text { portfolio return in exc } \\
\text { the CAPM and Fama } \\
\text { size and value premiu }\end{array}$ & $\begin{array}{l}\text { tion for the ri } \\
\text { bill divided by }\end{array}$ & $\begin{array}{l}\text { and Trade portfolic } \\
\text { viation of the exces } \\
\text { ressed on a constan }\end{array}$ & $\begin{array}{l}\text { Sharpe ratio is the } \\
\text { return regressions as } \\
\text { xcess return and the }\end{array}$ \\
\hline
\end{tabular}


Table 7. Predicting Economic Conditions

\begin{tabular}{|c|c|c|c|c|}
\hline & $\Delta \mathrm{IP}$ & $\Delta \mathrm{CPI}$ & Absolute $\Delta \mathrm{IP}$ & Absolute $\Delta \mathrm{CPI}$ \\
\hline \multicolumn{5}{|c|}{$\mathrm{K}=1$} \\
\hline Risky Return & $\begin{array}{l}2.992 \\
(2.36)\end{array}$ & $\begin{array}{l}3.043 \\
(3.16) \\
\end{array}$ & $\begin{array}{l}-1.255 \\
(-1.27)\end{array}$ & $\begin{array}{l}-0.147 \\
(-0.15)\end{array}$ \\
\hline Safe Return & $\begin{array}{l}-2.806 \\
(-1.05)\end{array}$ & $\begin{array}{l}-2.292 \\
(-1.73)\end{array}$ & $\begin{array}{l}-1.256 \\
(-0.83) \\
\end{array}$ & $\begin{array}{l}-2.291 \\
(-2.59) \\
\end{array}$ \\
\hline Correlation & $\begin{array}{l}-0.029 \\
(-0.23)\end{array}$ & $\begin{array}{l}0.118 \\
(1.54) \\
\end{array}$ & $\begin{array}{l}0.215 \\
(2.43) \\
\end{array}$ & $\begin{array}{l}0.132 \\
(2.10) \\
\end{array}$ \\
\hline \multicolumn{5}{|c|}{$\mathrm{K}=3$} \\
\hline Risky Return & $\begin{array}{l}13.494 \\
(3.400)\end{array}$ & $\begin{array}{l}5.305 \\
(2.83)\end{array}$ & $\begin{array}{l}-6.017 \\
(-1.70)\end{array}$ & $\begin{array}{l}0.121 \\
(0.10)\end{array}$ \\
\hline Safe Return & $\begin{array}{l}-5.889 \\
(-1.10)\end{array}$ & $\begin{array}{l}-6.99 \\
(-2.28)\end{array}$ & $\begin{array}{l}-2.122 \\
(-0.56)\end{array}$ & $\begin{array}{l}-6.208 \\
(-2.52)\end{array}$ \\
\hline Correlation & $\begin{array}{l}0.019 \\
(0.05)\end{array}$ & $\begin{array}{l}0.441 \\
(2.05)\end{array}$ & $\begin{array}{l}0.412 \\
(1.65)\end{array}$ & $\begin{array}{l}0.350 \\
(1.85)\end{array}$ \\
\hline \multicolumn{5}{|c|}{$\mathrm{K}=6$} \\
\hline Risky Return & $\begin{array}{l}21.095 \\
(3.30)\end{array}$ & $\begin{array}{l}5.281 \\
(2.36) \\
\end{array}$ & $\begin{array}{l}-6.095 \\
(-1.04)\end{array}$ & $\begin{array}{l}1.123 \\
(0.87)\end{array}$ \\
\hline Safe Return & $\begin{array}{l}-1.985 \\
(-0.25)\end{array}$ & $\begin{array}{l}-6.309 \\
(-1.22)\end{array}$ & $\begin{array}{l}-3.613 \\
(-0.75) \\
\end{array}$ & $\begin{array}{l}-6.731 \\
(-1.39) \\
\end{array}$ \\
\hline Correlation & $\begin{array}{l}0.357 \\
(0.57) \\
\end{array}$ & $\begin{array}{l}1.038 \\
(2.606)\end{array}$ & $\begin{array}{l}0.414 \\
(0.94) \\
\end{array}$ & $\begin{array}{l}0.775 \\
(2.12) \\
\end{array}$ \\
\hline \multicolumn{5}{|c|}{$\mathrm{K}=12$} \\
\hline Risky Return & $\begin{array}{l}26.636 \\
(4.61) \\
\end{array}$ & $\begin{array}{l}6.030 \\
(2.29) \\
\end{array}$ & $\begin{array}{l}2.165 \\
(0.42)\end{array}$ & $\begin{array}{l}5.066 \\
(2.27) \\
\end{array}$ \\
\hline Safe Return & $\begin{array}{l}6.053 \\
(0.42) \\
\end{array}$ & $\begin{array}{l}-10.718 \\
(-1.58)\end{array}$ & $\begin{array}{l}-1.261 \\
(-0.14)\end{array}$ & $\begin{array}{l}-11.050 \\
(-1.64)\end{array}$ \\
\hline Correlation & $\begin{array}{l}0.882 \\
(0.77) \\
\end{array}$ & $\begin{array}{l}1.796 \\
(2.81)\end{array}$ & $\begin{array}{l}0.610 \\
(0.78)\end{array}$ & $\begin{array}{l}1.652 \\
(2.66)\end{array}$ \\
\hline
\end{tabular}


Figure 1. One-Year Rolling Correlations
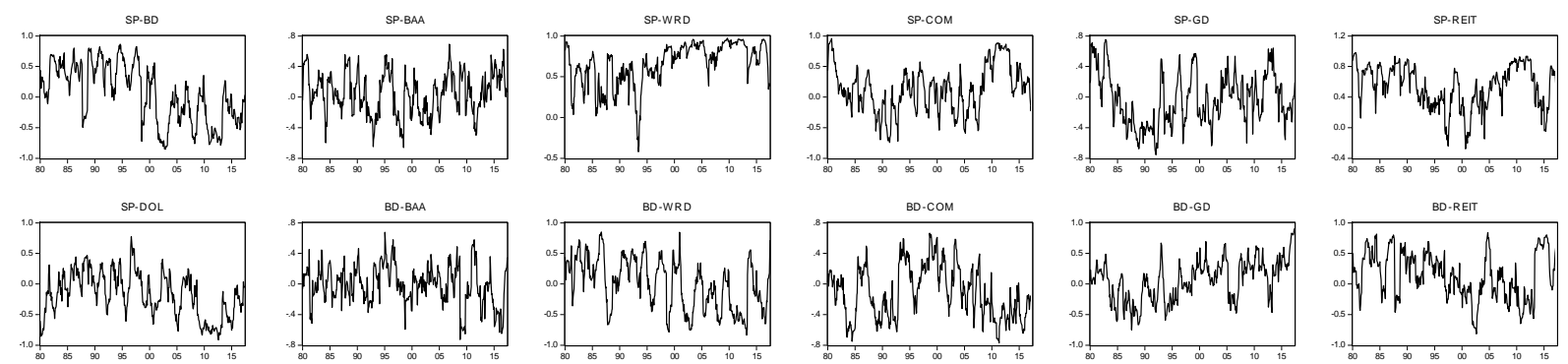

BD.DOL

BAA.WRD

BAA-COM
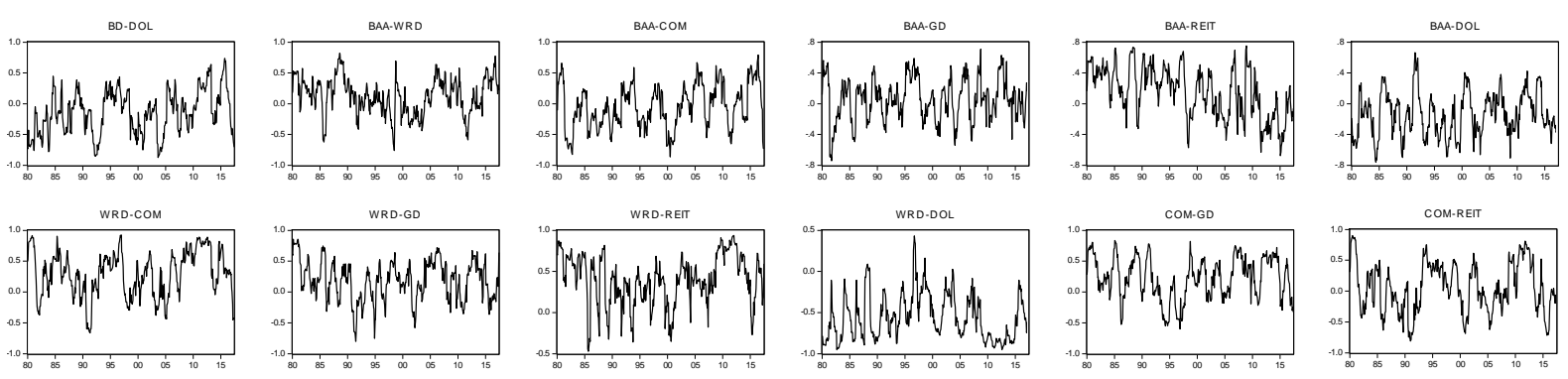

СOM-RET
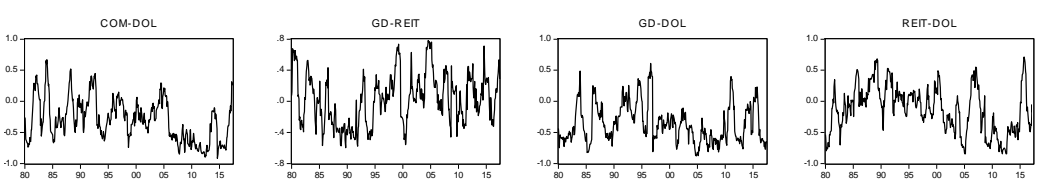

One-year rolling window correlations of the returns series for the S\&P500 index (SP), 10year Treasury bond index (BD), BAA-rated corporate bond index (BAA), world stock market index excluding the US (WRD), the general GSCI commodity index (COM), gold price (GD), real estate investment trust index (REIT) and the US dollar index (DOL). 
Figure 2. Stock and Bond Return Correlation - Rolling 1-Year/5-Year/DCC Stock and Bond Return Correlation

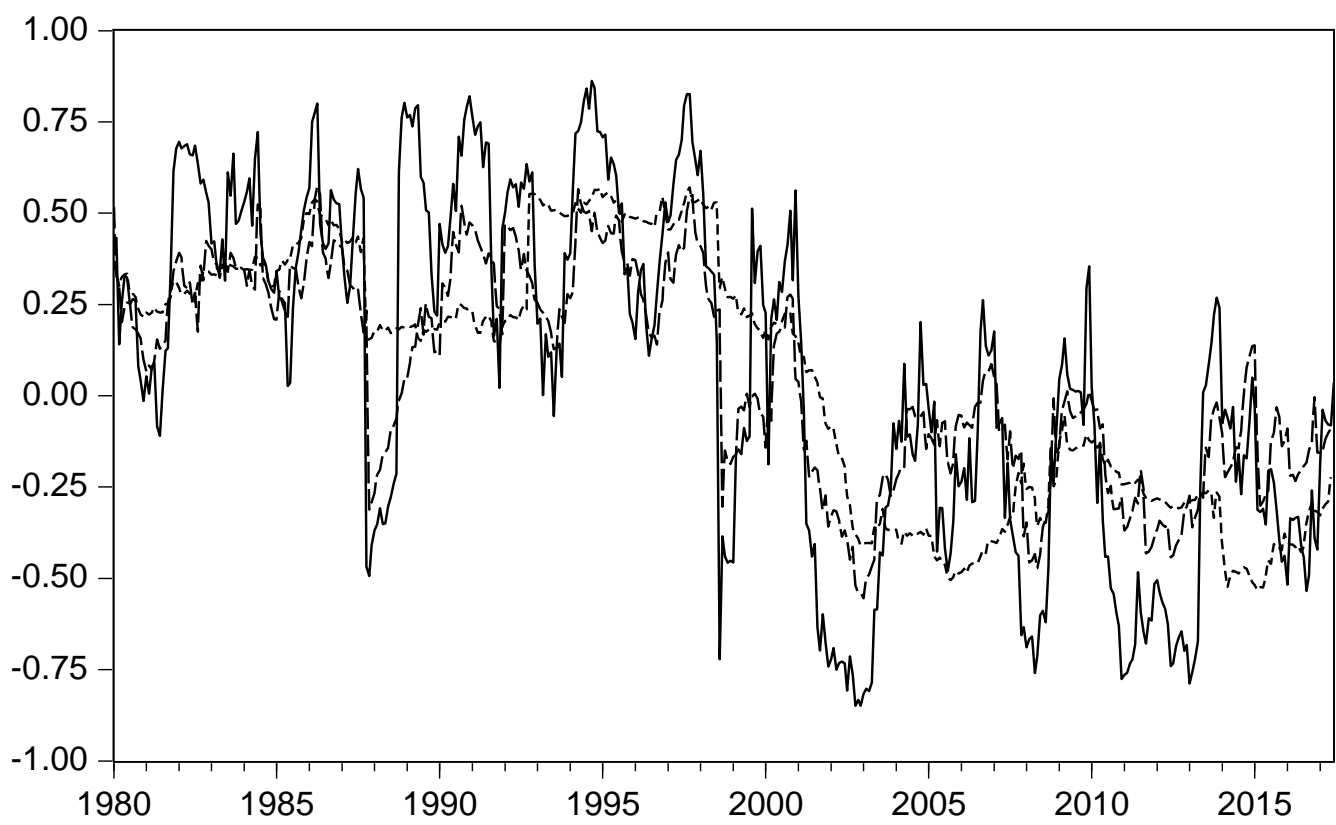

_ 1-Year Roll -----. 5-Year Roll ---. DCC

REIT and Dollar Correlation

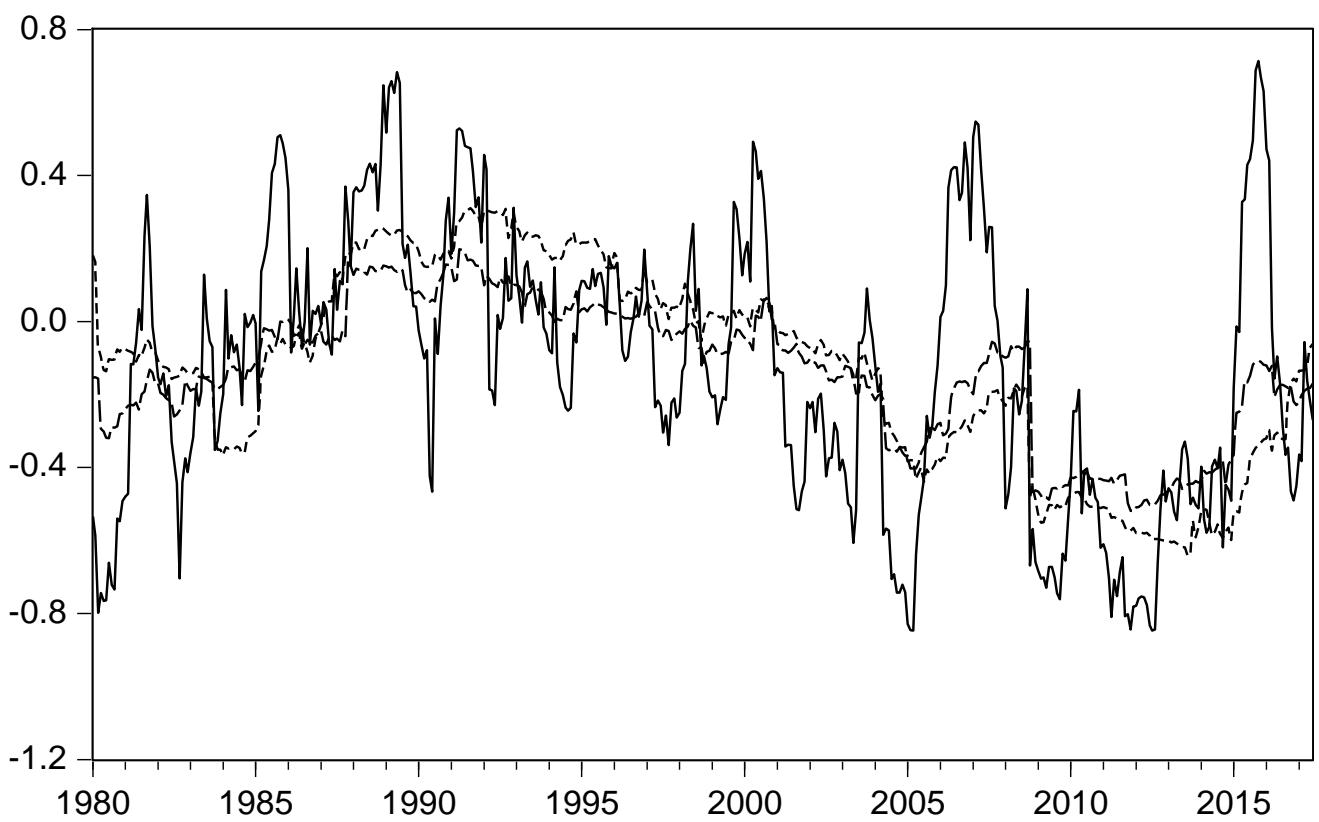

1-Year Roll -----. 5-Year Roll _-_. DCC 
Figure 3. Average Correlation and Max-Min Correlation
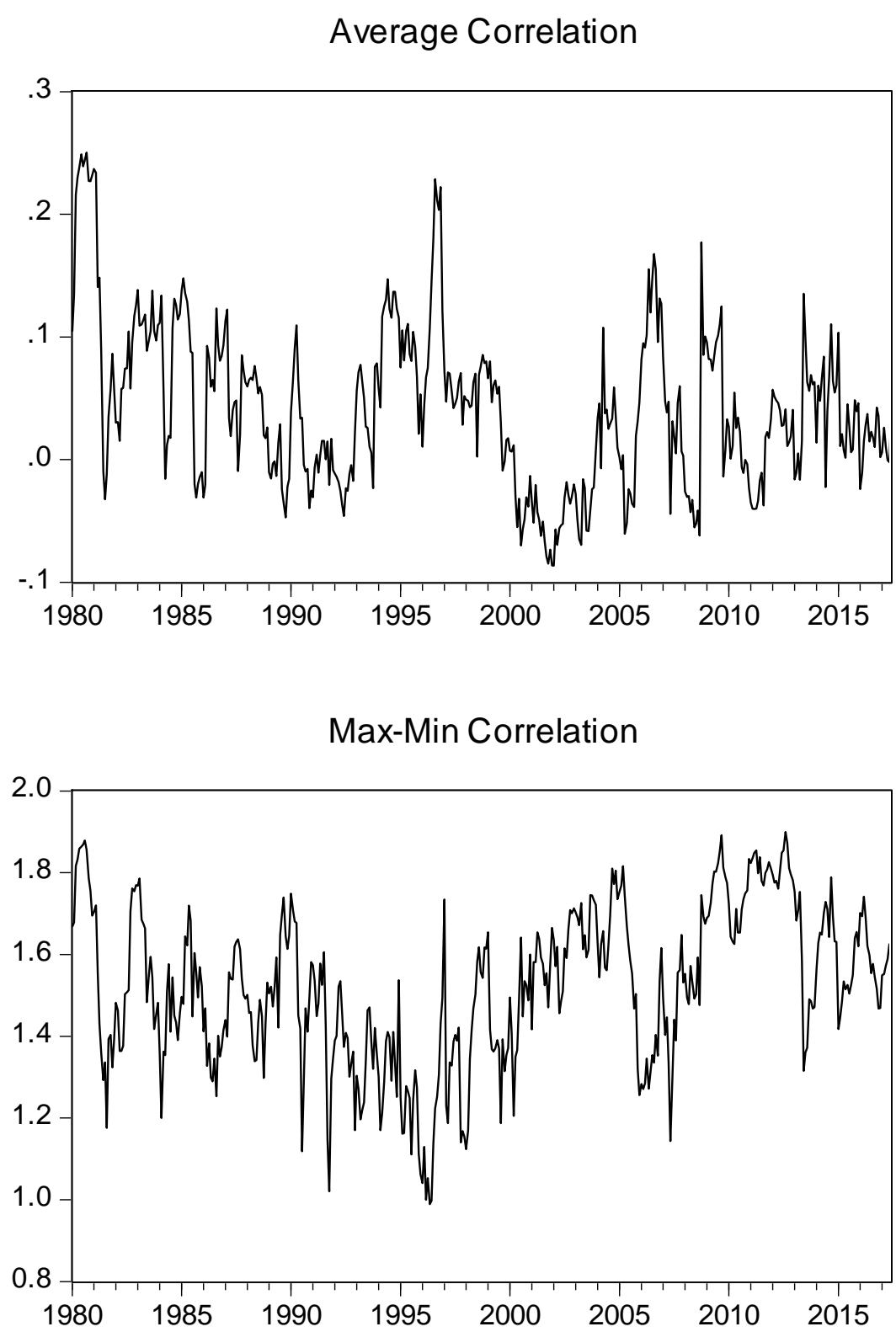
Figure 4. Stock and Bond Correlation and Markov Switching Regimes

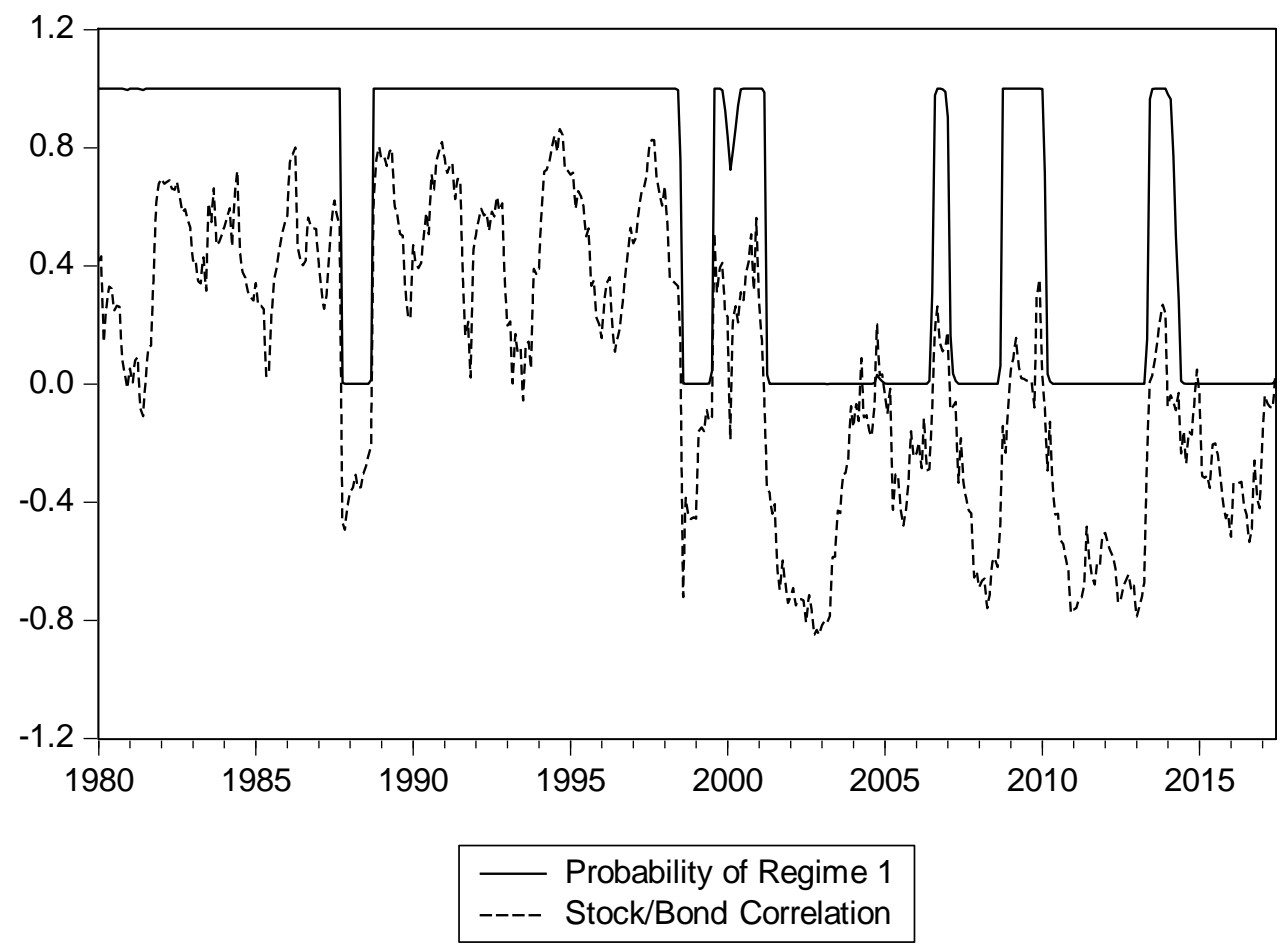


Figure 5. Safe and Risky Portfolio Correlation and Economic/Market Conditions
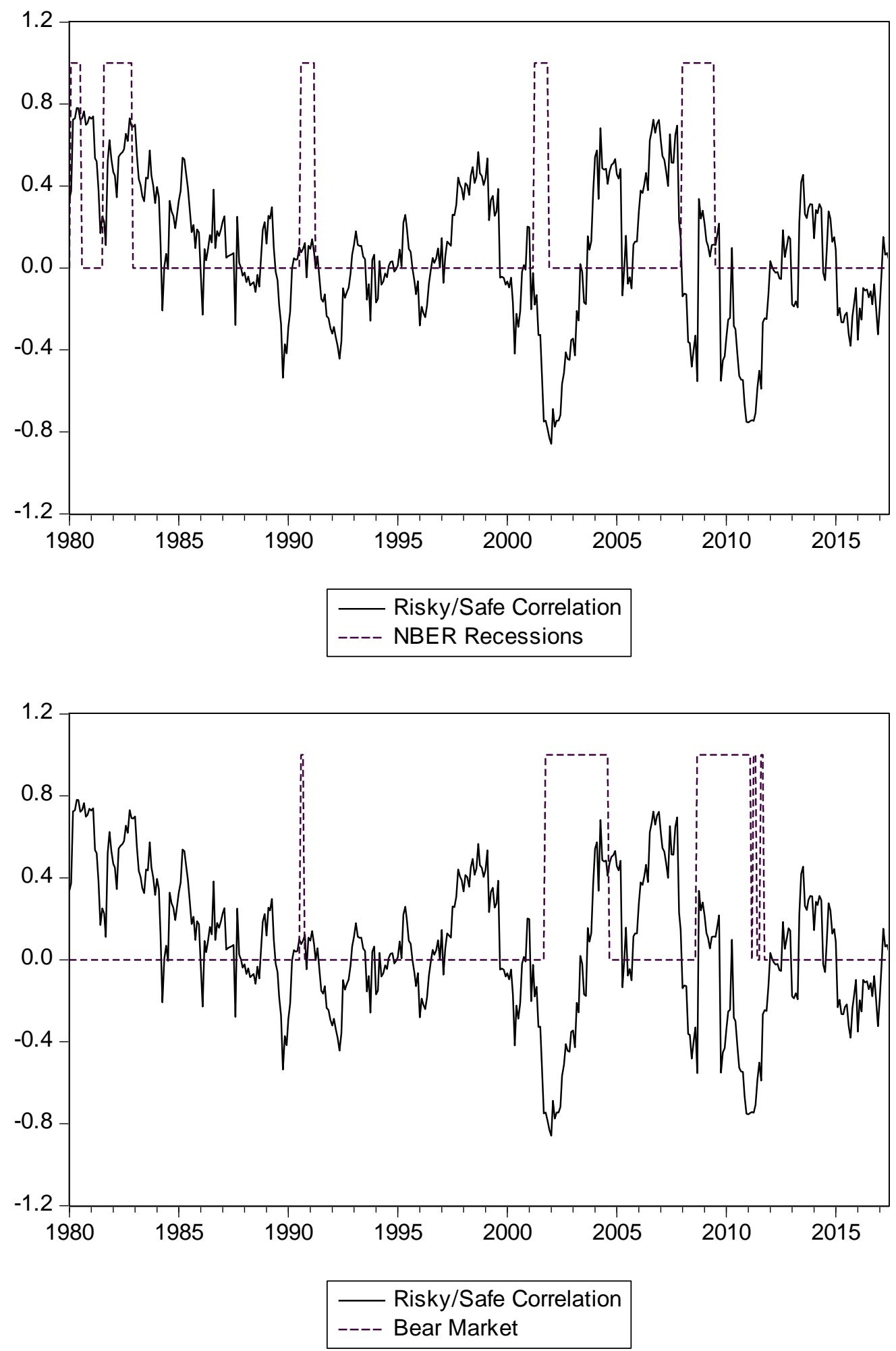